\title{
Contextualizing small business resilience during the COVID-19 pandemic: evidence from small business owner-managers
}

\author{
Elias Hadjielias (D) - Michael Christofi • \\ Shlomo Tarba
}

Accepted: 10 November 2021 / Published online: 28 January 2022

(C) The Author(s), under exclusive licence to Springer Science+Business Media, LLC, part of Springer Nature 2021

\begin{abstract}
In light of the unprecedented global crisis caused by the COVID-19 pandemic, resilient businesses are those more likely to make the transition to the post-COVID era. Our study draws on the concept of psychological resilience and focusses on individual owner-managers to the end of examining business resilience in the context of the COVID-19 pandemic. We conduct a longitudinal qualitative study, collecting data from 35 small business owner-managers between April and December 2020. Our findingswhich provide insights into the micro-underpinnings of the resilience exhibited by small business in response to the COVID-19 pandemic-illustrate the responses and resilient qualities of owner-managers at both the personal and leadership levels, which facilitate resilient actions at the small business level. By drawing on a psychological perspective, our study provides a novel conceptualization of small business resilience at the person-role-organization nexus.
\end{abstract}

E. Hadjielias $(\bowtie) \cdot$ M. Christofi

School of Management and Economics, Cyprus University of Technology, 30 Archbishop Kyprianos Street,

3036 Limassol, Cyprus

e-mail: elias.hadjielias@cut.ac.cy

M. Christofi

e-mail: michael.christofi@ cut.ac.cy

S. Tarba

Birmingham Business School, University

of Birmingham, University House, Edgbaston Park Road,

Birmingham B15 2TY, UK

e-mail: s.tarba@bham.ac.uk
Plain English Summary The psychological resilience of owner-managers provides novel insights towards a better understanding of small business resilience during exogenous shocks, such as the COVID19 pandemic. Psychological resilience involves an individual's ability to adapt or thrive in the face of life's adversities and uncertainties. We conduct a longitudinal qualitative study, collecting data from 35 small business owner-managers between April and December 2020. We reveal a sequential process centred on owner-managers and on their abilities to build-up or strengthen any personal and leadership resilient capacities, which appear to be prerequisites for the establishment of resilient actions at the level of the small business. We contribute theoretically by conceptualizing the links and path dependencies between personal, leadership (role), and organizational resilience in small businesses. In conclusion, our study provides practical implications on essential personal-level responses that can guide the leadership role of owner-managers in the midst of the continuing COVID-19 pandemic.

Keywords Small business - Psychological resilience · Organizational resilience $\cdot$ Leadership resilience $\cdot$ Owner-manager $\cdot$ COVID-19 pandemic

JEL classification L26 


\section{Introduction}

The SARS-CoV-2 virus (which is causing the COVID-19 pandemic) first emerged in Wuhan, China, in December 2019, and immediately had a significant impact on people, businesses, the economy, and society as a whole (Fairlie \& Fossen, 2021; McKibbin \& Fernando, 2020). In a race to mitigate the spread of COVID-19, most nations have responded by implementing a variety of measures involving closing or hardening national borders; locking down and quarantining regions or cities; imposing curfews, limitations to people's movements, and physical distancing; banning events and gatherings; and restricting the ways in which businesses could operate, including closing nonessential ones (Anderson et al., 2020). Due to the COVID-19 pandemic and the ensuing governmental lockdown measures, socioeconomic systems across the globe are transitioning to a 'new normal', with changes in the ways people interact (Brammer, Branicki, \& Linnenluecke, 2020) and businesses transact and with higher levels of economic uncertainty (Brammer et al., 2020; Donthu \& Gustafsson, 2020).

Many businesses around the world have been largely affected by the COVID-19 pandemic (Brammer et al., 2020; Donthu \& Gustafsson, 2020) with varied responses. Smaller, financially vulnerable, businesses faced closure or other serious economic disruptions (Belitski et al., 2021; Khlystova et al., 2022; Torrès et al., 2021), while healthy firms in sectors heavily impacted by lockdown measures (e.g. travel, tourism, and event organizers) were forced to reduce their activities or to engage in cost-cutting measures (Nepal, 2020). Conversely, other businesses responded with business renewal and new products or processes (Ratten, 2020; Seetharaman, 2020). For instance, certain companies shifted to platformbased business models and established online selling channels (Baker et al., 2020). Past research has highlighted the need for businesses to bring about changes suited to shield or strengthen them against any threats brought by exogenous shocks (Korber \& McNaughton, 2018), including the survivability ones associated with the COVID-19 pandemic (Ratten, 2020; Seetharaman, 2020). Given that effective business response to exogenous shocks has been associated with resilience (Dahles \& Susilowati, 2015; Iborra, Safón, \& Dolz, 2019; Ortiz-de-Mandojana
\& Bansal, 2016), it is likely that resilient firms will effectively make the transition to the post-COVID era (Bryce et al., 2020).

In smaller businesses, owner-managers usually wield a pervasive influence (Gibson \& Cassar, 2005; Mc Cartan-Quinn \& Carson, 2003), playing a crucial role in filling any resource gaps and engaging in practices (e.g. innovation) and making decisions aimed at keeping the business viable in times of crisis (Hutchinson, 1995; Kevill, Trehan, \& Easterby-Smith, 2017; Werner, Schröder, \& Chlosta, 2018). Conversely, any vulnerability exhibited by owner-managers in coping with adverse circumstances (e.g. through increased levels of stress, anxiety, burnout, rumination, and general negativity) can diminish the chances for small business survival (Chadwick \& Raver, 2020; Schonfeld \& Mazzola, 2015; Torrès et al., 2021). To study the role played by owner-managers faced by adverse exogenous shocks, we focussed on individual resilience, which is an intrapersonal resource linked to 'the sum total of dynamic psychological processes that permit individuals to maintain or return to previous levels of well-being and functioning in response to adversity' (Lee et al., 2013: p. 327). A handful of studies have hinted that the resilience of small businesses is influenced by the practices and behaviours enacted by key individuals within them (e.g. Bullough, Renko, \& Myatt, 2014; Herbane, 2019; Santoro, Messeni-Petruzzelli, \& Del Giudice 2021; Shepherd, Saade, \& Wincent, 2020), including their owner-managers (Branicki, Sullivan-Taylor, \& Livschitz, 2018; Herbane, 2019). For instance, Herbane (2019) highlighted that SME resilience is influenced by the activities and decisions related to planning, networks, learning, and location made by individual owner-managers.

Despite increased evidence for the influence of factors of various levels on business or organizational resilience, the resilience literature offers insufficient understanding of the ways in which individual and organizational resilience interact within small business settings (Santoro et al., 2021). At the same time, individual resilience has not been sufficiently empirically examined in the small business literature (Branicki et al., 2018; Santoro et al., 2021). The few studies which have focussed on exploring individual ownermanager resilience have produced inconsistent conceptualizations of the topic (Ayala \& Manzano, 2014; Herbane, 2019; Santoro et al., 2021), have made 
minimal use of the extant literature on psychological resilience-which may explain individual resilience (Lee et al., 2013) — and have paid no attention to the process through which psychological resilience benefits individuals and organizations. This fragmented literature and the weak conceptual basis of the concept is problematic (Chadwick \& Raver, 2020), consequently hampering our knowledge with regard to the role played by the owner-managers' (psychological) resilience on that of small businesses in the presence of adverse exogenous conditions such as the COVID-19 pandemic.

In our study, we applied the concept of psychological resilience to understand its processes and influences on small business resilience in the context of the COVID-19 pandemic, which makes the business environment more uncertain (Knight, 1921; Sharma et al., 2020) and threatens small business survival (Doern, 2021). Psychological resilience involves the ability of an individual to adapt or thrive in the face of life's adversities, uncertainties, and difficult circumstances (Fletcher \& Sarkar, 2013; Kong et al., 2015). Moreover, psychological resilience is a dynamic concept that changes over time and can be encouraged and developed (Ayala \& Manzano, 2014). Yet, most empirical studies focussing on psychological resilience have been of a cross-sectional nature (Lee et al., 2013). This has caused difficulties in the interpretation of the findings related to the concept. This is because, based on the various characteristics exhibited by the business landscape throughout an exogenous crisis, the observation of psychological resilience at different points in time may reflect (i) the influence of psychological resilience on ownermanager resilience and business resilience, (ii) the effects of various mechanisms on the development of resilience over time, or (iii) the various benefits that resilience provides to businesses.

We sought to contribute to the small business literature by carrying out a longitudinal qualitative study during the COVID-19 pandemic on the basis of data collected from small business owner-managers. Given the central role played by owner-managers within small businesses (Kevill et al., 2017), their psychological resilience may influence that of the business. Consequently, we addressed the following research question: How does psychological resilience, at the individual owner-manager level of analysis, foster the resilience of small businesses within the context of the
COVID-19 pandemic? We asserted that those individual owner-managers who draw upon their psychological resilience as a trait and process (a) make broad cognitive appraisals that the negative consequences of the pandemic and the negative climate that creates anxiety and stressors are seen as challenges that can be minimized and eventually overcome, (b) engage in a reflective process, which enables them to draw on past knowledge and life events to engage in adaptive behaviours, (c) develop proactive strategies and processes for their companies, and hence (d) help their firms to bounce back from the negative effects of the COVID-19 pandemic. We explored this theoretical perspective by means of a longitudinal study whereby we followed small business owners in Cyprus as they operated their businesses from the early stages of the pandemic (April 2020) until December 2020. Hence, our research provides theoretical coherence suited to explain the mechanisms whereby psychological resilience enables the individual owner-managers of small businesses to cope more efficiently and effectively with the stressful circumstances created by the pandemic and thus remain in business.

We contribute to the literatures on small business resilience and organizational resilience in five distinct ways. First, we contribute theoretically by conceptualizing the links and path dependencies between personal, leadership (role), and organizational resilience in small businesses. Through a bottom-up theorization, by identifying the resilience of individual owner-managers as a key prerequisite for resilient actions at the business level, we advance the knowledge on concepts, relationships, and processes that have been largely ignored in the small business and organizational resilience literatures. Second, by drawing on psychological resilience (Fletcher \& Sarkar, 2013; Kong et al., 2015), we introduce a novel psychological perspective to the study of organizational resilience. Third, we contribute theoretically to the small business resilience literature through contextbased theorization, contextualizing our findings and theoretical insights within the COVID-19 pandemic. Fourth, we provide new empirical knowledge on the micro-underpinnings of small business resilience. Fifth, we contribute methodologically to the organizational resilience literature by performing a multilevel analysis (i.e. at the individual and organizational levels) to examine small business resilience. 


\section{Theoretical background}

In the business literature, resilience has been largely equated with the capacity of a firm to respond effectively to natural (e.g. floods or earthquakes) and man-made disasters (e.g. financial crises or wars) (Dahles \& Susilowati, 2015; Iborra, Safón, \& Dolz, 2019; Ortiz-de-Mandojana \& Bansal, 2016) through changes aimed at shielding or improving the business under harsh conditions (Korber \& McNaughton, 2018). The smaller firm, as a unit, has been the focus in studies on resilience (Audretsch \& Belitski, 2021; Iborra et al., 2019; Torres, Marshall, \& Sydnor, 2019). Given the prevalence of small firms across sectors (García, Castillo, \& Durán, 2012) and their resource limitations (Petrou et al., 2020), small firm resilience has serious implications for the sustainability of local and national socioeconomic systems (Adekola \& Clelland, 2020; Hadjielias et al., 2022). Yet, the firm features as a dominant unit in the study of resilience in the presence of exogenous shocks (e.g., Dahles \& Susilowati, 2015; Ortiz-de-Mandojana \& Bansal, 2016), despite increasing calls to shed light on the micro-dynamics of organizational resilience, including the role of individuals (Branicki et al., 2018).

Resilient individuals, particularly owner-managers, have been identified as being important to the survival of small firms (Ghobakhloo \& Tang, 2013; Herbane, 2019; Kevill et al., 2017) because they benefit them with strong intrapersonal propensities to look for alternatives under adverse conditions and with the ability to deal with complex situations and identify solutions (Renko, Bullough, \& Saeed, 2021; Santoro et al., 2021). Interestingly, while a number of small firm owner-managers can be resilient to adverse events and able to keep functioning positively, others experience considerable disruption. In explicating the heterogeneity of findings on individual resilience, prior research has accentuated both the individual owner-managers' pre-adversity resource endowments and their cognitive and behavioural responses to such events (Kevill et al., 2017; Shepherd, Saade, \& Wincent, 2020).

Those small business studies that have argued for the importance of individual resilience have pointed to the relevance of owner-manager resilience in understanding small business resilience (Bullough et al., 2014; Herbane, 2019; Santoro et al., 2021;
Shepherd et al., 2020). While owner-managers can be present in both family- and nonfamily-owned firms (Chrisman et al., 2016), the former usually pursue goals that involve increasing both financial and socioemotional wealth (Chrisman et al., 2016; Rousseau et al., 2018) and exhibit stronger stewardship towards the firm (Miller \& Le Breton-Miller, 2006; Hadjielias, Christofi, \& Tarba, 2021). Challenging the wellestablished notion and alluding to the fact that the current literature on family-owned businesses overlooks the contribution of owner-managers in practicing resilience, Conz, Lamb, and De Massis (2020) revealed that resilience is not universal, but multifarious, and that the owner-managers' comprehension of resilience determines how it is actually practiced. Despite the limited insights into the influence of owner-manager resilience on family business resilience, long-term family ownership orientation and the desire to transfer the business to future generations have been identified as providing the social, financial, and emotional capital required to successfully cope with emergencies (Calabrò, Frank, Minichilli, \& Suess-Reyes, 2021; Salvato, Sargiacomo, Amore, \& Minichilli, 2020).

While how individual owner-manager resilience influences small business resilience remains to be seen, in our study, we argued that a focus on the owner-manager can unlock hidden micro-dynamics suited to provide new understandings of resilience in the midst of exogenous shocks such as the COVID19 pandemic. To study owner-manager resilience, we drew on the concept of psychological resilience, which refers to 'the ability to thrive in the face of risk and adversity, which is crucial for individuals' mental and physical health' (Kong et al., 2015: p. 165). Psychological resilience distinguishes those individuals who are able to withstand or even thrive when experiencing pressures and difficult circumstances in their lives (Fletcher \& Sarkar, 2013), such as poverty (Garmezy, 1991). Psychological resilience has been conceptualized as either a trait or a process (Fletcher \& Sarkar, 2013). In our study, we value both dimensions of psychological resilience. As a trait, psychological resilience involves a set of personal characteristics or abilities that enable individuals to adapt to adverse circumstances (Connor \& Davidson, 2003). These characteristics are clustered into protective and promotive traits, both of which are essential for individual resilience 
(Fletcher \& Sarkar, 2013). 'Protective' traits are the characteristics-such as self-efficacy (Gu \& Day, 2007), self-esteem (Kidd \& Shahar, 2008), and positive emotions (Tugade \& Fredrickson, 2004) - that enable individuals to shield themselves from any potential negative effects of an experience. 'Promotive' traits are the characteristics that enable individuals to gain benefits and succeed in the presence of negative events (Fletcher \& Sarkar, 2013). As a process, psychological resilience is linked to a dynamic process whereby individuals engage with the self to overcome stressful life events (Flach, 1988; Moenkemeyer, Hoegl, \& Weiss, 2012). The process of psychological resilience explicates the value of self-reflection, which enables individuals to learn from past events and engage in adaptive behaviours (Crane et al., 2020).

Psychological resilience has been mainly used in relation to new venture creation (Chadwick \& Raver, 2020), thus contributing to the establishment of the entrepreneurial resilience construct and highlighting that entrepreneurs need to be resilient in order to start new businesses in the midst of uncertainty (Bullough \& Renko, 2013). However, in the entrepreneurship literature, entrepreneurial resilience has been largely used as a metaphor and not sufficiently explored empirically (Chadwick \& Raver, 2020). The few studies focussing on individual resilience in small firms have linked entrepreneurial resilience with small business survival and resilience (Branicki et al., 2018; Santoro et al., 2018). However, small business resilience has not been explored from a psychological resilience perspective, which has a pure focus on the individual. As clarified by Branicki et al. (2018), entrepreneurial resilience is not the same as the psychological resilience of the individual. Entrepreneurial resilience is bound within an entrepreneurial context, it does not necessarily refer to the individual, and may involve emotions, perceptions, and abilities that are not necessarily linked to individual traits (Bernard and Barbosa, 2016; Branicki et al., 2018). Instead, an individual's psychological resilience is firmed within specific personal traits at the protective-promotive nexus (Fletcher \& Sarkar, 2013), which extends beyond new venture creation and the organizational context (Branicki et al., 2018). In our study, we drew upon psychological resilience to examine the influence of individual resilience, as we posited that certain traits and personal processes of small firm owner-managers could be relevant to the resilience of their firms.

Considering the above, we aimed at gaining a multi-level understanding of resilience, focussing on both its individual and business forms. Given the central role played by owner-managers within smaller business settings (Ghobakhloo \& Tang, 2013; Kevill et al., 2017), we drew upon psychological resilience to examine the way their resilience influences that of their small businesses. Thus, our study had the potential to uncover the micro-dynamics found within small business resilience, which had hitherto largely been latent in the literature. Additionally, our study involved an attempt to contextualize (Tsang, 2013) the individual-firm resilience nexus in order to provide insights into resilience in relation to a specific external shock. Research, especially when conducted within the small business context, had not hitherto sufficiently drawn on contextual explanations of resilience (e.g., Branicki et al., 2018). We argued that contextualization is essential in understanding the specificities of the COVID-19 crisis in regard to the resilience of both owner-managers and their small firms.

\section{Methods}

\subsection{Research design}

Qualitative inquiry is suited to answering 'how' questions' (Yin, 2018) by enabling participants to articulate the phenomena occurring within organizations (Pratt, 2009) and by providing contextualized explanations for them (Tsang, 2013). In addition, longitudinal studies are important in understanding the dynamic interplay between various concepts (Mosey, $\&$ Wright, 2007). Thus, to learn more about the way psychological resilience-at the individual ownermanager level of analysis - fosters the resilience of small businesses within the context of the COVID19 pandemic, we drew on a qualitative, longitudinal research design. In line with Hollensbe et al. (2008), we conducted interviews aimed at gathering different 'slices' of data over time, created categories by coding the data, engaged in ongoing comparisons between our findings and extant literature, and concluded our data gathering and coding when no new 
findings emerged, thus achieving theoretical saturation. Moreover, as proposed by Hollensbe et al. (2008), our research design did not take a purely grounded approach, in that we analysed 'slices' of data over time, and not across different data sources. Our longitudinal, qualitative study design involved conducting interviews with small business ownermanagers during two sessions: one between April and May 2020 and a second 5 to 6 months later (October to December 2020), which is standard practice, as shown in longitudinal studies published in top journals within the management field (e.g., Liu et al., 2015; Autio, George, \& Alexy, 2011; Hollensbe et al., 2008).

\subsection{Research site and context}

Our study gathered its data from owner-managers of small privately owned businesses located in Cyprus, a European Union island country situated in the eastern Mediterranean Sea. As its economy is dominated by small businesses, Cyprus is ideally suited to the study of their resilience (Hadjimanolis, 1999; Leonidou et al., 2016a, b). Specifically, 99\% of all the country's firms are classified as small by the European Commission, as they employ fewer than 50 employees (European Commission, 2019). Small Cypriot businesses account for $64 \%$ of the country's employment and generate $55.9 \%$ of the total value added, statistics that are both well above the respective EU averages of $49.8 \%$ and $38.4 \%$ (European Commission, 2019). Most small Cypriot businesses-approximately $90 \%$ - are owned and/or managed by members of a founding family (Leonidou et al., 2016a, b; Mandl, 2008) and are intended to be handed down to the next generation or involve an actual generational movement (Chua, Chrisman, \& Sharma, 1999; Heck $\&$ Trent, 1999). Small Cypriot family businesses are usually owned and managed by a few controlling family members, and it is common for a single family member to exercise effective control of the firm (Leonidou et al., 2016a, b; Mandl, 2008). Nevertheless, not all owner-managed small firms are family businesses. For instance, a significant proportion of small businesses across the world are single founder-owned and managed (Deb \& Wiklund, 2017; Langowitz \& Allen, 2010), and Cyprus is not an exception. Consequently, we focussed on both family and non-family owner-managed small businesses, which involve a single person exercising control of both their ownership and management (Chrisman, Memili, \& Misra, 2014).

As in many other countries across the globe, the COVID-19 pandemic and its associated lockdown measures and other restrictions have hit the Cypriot economy and its business landscape hard (ICAEW, 2020; PWC, 2020). The pandemic has forced the Cypriot government to impose a set of measures aimed at reducing the number of COVID-19 cases in the country, including national and regional lockdowns, the suspension of business activities, restrictions on retail sales, encouragement of working from home, and the closure of schools and educational institutions (Reuters, 2021). The European Investment Bank (2021) highlighted the major impact of the COVID-19 pandemic on Cypriot businesses, leading to the closure of many smaller firms and forcing a substantial number of others to abandon or delay their investments. Yet, through their experience of the pandemic and of the related restrictions, small Cypriot businesses have embraced or are ready to adopt digital technologies suited to introduce changes in the way they operate and reach their customers (European Investment Bank, 2021).

\subsection{Sampling and data collection}

In line with the practices found in studies published in top business journals (e.g. Grinevich, Huber, KarataşÖzkan, \& Yavuz, 2019; Theodoraki, Messeghem, \& Rice, 2018; Hollensbe et al., 2008), we conducted a qualitative longitudinal study involving interviews with the individual owner-managers of 35 small Cypriot businesses that met specific criteria. To select these companies, we needed to conduct a purposive sampling process (Bell, Bryman, \& Harley, 2018; Yin, 2018; Etikan, Musa, \& Alkassim, 2016). In particular, the target population had to meet the following criteria. First, firms had to be categorized as small. For this criterion, we followed Lai, Saridakis, Blackburn and Johnstone (2016) and adopted the standard European enterprise size definition, which states that businesses with fewer than 50 employees are considered small. Second, our sample small businesses had to be operating in sectors affected by the COVID 19 pandemic (Pantano et al., 2020). According to McKinsey and Company (2020), these sectors include: arts, entertainment, and recreation; 
accommodation, food, and beverage; educational services; transportation and warehousing; manufacturing; wholesale trade; administrative and support services; utilities; finance and insurance; construction; retail trade (particularly of non-essential goods); professional and consultancy services; information services; and healthcare. Thus, we excluded, for instance, pharmacies or supermarkets, as such businesses deal in essential goods and had remained in full operation throughout the pandemic (Roggeveen $\&$ Sethuraman, 2020). Third, we chose firms that had survived the COVID-19 pandemic. While our attention was not on firm survival, we expected firms that had survived to exhibit resilience (Gölgeci \& Kuivalainen, 2020; Ramezani \& Camarinha-Matos, 2020). Fourth, to explore the ways in which the psychological resilience of the individual owner-manager develops over time, and how it contributes to the development of firm-level resilience, it was important to study stand-alone (privately held) businesses that were run by a sole founder or a successor (as general manager/CEO) who owned the firm and controlled its decision-making (Lichtenstein \& Brush, 2001; Lozano, Martínez, \& Pindado, 2016). We focussed solely on our sample firms' owner-managers (Ghobakhloo \& Tang, 2013; Kevill et al., 2017) because of their pervasive influence (Gibson \& Cassar, 2005; Mc Cartan-Quinn \& Carson, 2003) and of the fact that our study sought explanations on the way these actors' psychological resilience links to firm resilience. Following practices drawn from the literature (e.g. Grinevich, et al., 2019; Autio et al., 2011), we searched for firms that met our criteria by using publicly available directories, such as those published by local (Cypriot) industry and commerce associations, and firm websites. Our target list eventually included the owner-managers of 485 small businesses. Of these, 35 agreed to take part in the research. Table 1 provides a brief description of our sample.

Prior to finalizing the interview guides and ensure that the interview questions were evocative and comprehensible by the respondents, we conducted pilot interviews with three individual owner-managers of small businesses that were not included in our final sample. Based on this pilot test, we streamlined our interview guides and rephrased some of the questions (Hollensbe et al., 2008). Moreover, before starting the interview, we reassured the participants of their full anonymity and of the confidentiality of the conversations (Grinevich, et al., 2019). We conducted two 35-interview sessions: the first included interviews that lasted 30 to $40 \mathrm{~min}$ each and the second 1-h interviews. The interviews were semi-structured in order to facilitate the flexible expression of the individual owner-managers' thoughts, emotions, and ideas and to provide us with the possibility to compare responses across subsequent interviews and draw lessons (Autio et al., 2011). This data collection approach enabled us to ask both set of questions and additional ones as the interviews unfolded and insights emerged (Williams \& Shepherd, 2016). Each participant was invited to choose the language in which he/she preferred to be interviewed (Williams \& Shepherd, 2016), and all selected Greek.

The interview guides for both sessions were developed based on the need to collect data framed within existing conceptualizations (e.g. the trait and process dimensions of psychological and business resilience) (Timmermans \& Tavory, 2012) and in line with previous qualitative studies focussing on resilience during a specific crises or catastrophic events (e.g. Williams $\&$ Shepherd, 2016). The interview guide for the first session included various broad themes (McAdam, Harrison \& Leitch, 2019), including (1) general background information on the individual owner-managers and a description of their duties within their businesses, (2) company information, (3) a description of what had happened following the announcement of COVID-19 as a pandemic, (4) the business responses and changes made due to the pandemic, (5) the business characteristics and abilities in dealing with the pandemic at the business level, (6) the impact of the pandemic on the individual owner-manager (wellbeing, emotions and mindset), (7) the owner-managers' personal traits and response to the pandemic conditions, (8) the owner-managers' response to the pandemic from their leadership capacity, and (9) the impact of the owner-managers on the operation of their businesses during the pandemic. Following Harries, McEwen, and Wragg (2018) and Williams and Shepherd (2016), the interview protocol for the second session was structured in an effort to trigger the production of a narrative and included a general question about how things had gone for individual owner-managers and their organizations following the months that had passed since their first interviews, as well as specific questions about their experiences from the ongoing pandemic, challenges encountered, 
Table.1 Profiles of participating businesses and interviewees

\begin{tabular}{|c|c|c|c|c|c|c|c|c|c|}
\hline N. & $\begin{array}{l}\text { Company pseu- } \\
\text { donym }\end{array}$ & $\begin{array}{l}\text { Owner- } \\
\text { manager } \\
\text { pseudonym }\end{array}$ & $\begin{array}{l}\text { Industry/activ- } \\
\text { ity }\end{array}$ & $\begin{array}{l}\text { Business } \\
\text { location } \\
\text { (region) }\end{array}$ & $\begin{array}{l}\text { Family busi- } \\
\text { ness (FB)/non- } \\
\text { family business } \\
(\mathrm{NF})^{\mathrm{i}}\end{array}$ & $\begin{array}{l}\text { Size - \# } \\
\text { employ- } \\
\text { ees }\end{array}$ & $\begin{array}{l}\text { Year of } \\
\text { establish- } \\
\text { ment }\end{array}$ & $\begin{array}{l}\text { \# of } \\
\text { inter- } \\
\text { views }\end{array}$ & $\begin{array}{l}\text { Interview } \\
\text { periods } \\
(2020)\end{array}$ \\
\hline 1 & ReMark & Nikos & $\begin{array}{l}\text { Market } \\
\text { research }\end{array}$ & Nicosia & NF & 5 & 2011 & 2 & Apr, Oct \\
\hline 2 & $\begin{array}{l}\text { Arrow Con- } \\
\text { sultants }\end{array}$ & Andreas & $\begin{array}{l}\text { Business con- } \\
\text { sultancy }\end{array}$ & Nicosia & NF & 7 & 2010 & 2 & Apr, Oct \\
\hline 3 & Bella Me & Maria & Beauty salon & Pafos & NF & 6 & 2006 & 2 & May, Nov \\
\hline 4 & Excelsior & Costas & $\begin{array}{l}\text { Research } \\
\text { centre }\end{array}$ & Limassol & NF & 23 & 2009 & 2 & Apr, Oct \\
\hline 5 & e-Masters & Petros & $\begin{array}{l}\text { Electronics } \\
\text { store }\end{array}$ & Larnaca & FB & 7 & 2004 & 2 & May, Nov \\
\hline 6 & Gourmet AA & Stathis & Restaurant & Limassol & FB & 6 & 1992 & 2 & May, Nov \\
\hline 7 & QualiTrade & Anna & $\begin{array}{l}\text { Construction } \\
\text { material } \\
\text { importer }\end{array}$ & Limassol & FB & 12 & 1986 & 2 & May, Nov \\
\hline 8 & Sweet Ice & Stelios & $\begin{array}{l}\text { Ice cream } \\
\text { producers }\end{array}$ & Nicosia & NF & 7 & 2009 & 2 & May, Dec \\
\hline 9 & X-Style & Giorgos & $\begin{array}{l}\text { Hairdressing } \\
\text { salon }\end{array}$ & Limassol & FB & 4 & 1987 & 2 & May, Nov \\
\hline 10 & Bean café & Eleni & Coffee shop & Famagusta & FB & 5 & 2006 & 2 & May, Dec \\
\hline 11 & Physio Clinic & Christos & Physiotherapist & Pafos & FB & 8 & 2007 & 2 & May, Nov \\
\hline 12 & TRC Audit & Lakis & Audit office & Larnaca & FB & 11 & 2008 & 2 & Apr, Oct \\
\hline 13 & Blue bear & Pavlos & $\begin{array}{l}\text { Digital market- } \\
\text { ing company }\end{array}$ & Limassol & NF & 7 & 2011 & 2 & May, Dec \\
\hline 14 & Guru media & Kyriakos & $\begin{array}{l}\text { Social media } \\
\text { company }\end{array}$ & Larnaca & NF & 5 & 2010 & 2 & Apr, Oct \\
\hline 15 & Data Stars & Xenios & $\begin{array}{l}\text { Software con- } \\
\text { sulting and } \\
\text { development }\end{array}$ & Limassol & FB & 13 & 2007 & 2 & Apr, Oct \\
\hline 16 & $\begin{array}{l}\text { Muscle Uni- } \\
\text { verse }\end{array}$ & Evgenia & Gym & Pafos & NF & 6 & 2009 & 2 & Apr, Oct \\
\hline 17 & Futures & Demetris & $\begin{array}{l}\text { Educational } \\
\text { programmes }\end{array}$ & Larnaca & FB & 15 & 2004 & 2 & May, Dec \\
\hline 18 & Business Serve & Chara & $\begin{array}{l}\text { Business } \\
\text { consultancy } \\
\text { and training } \\
\text { centre }\end{array}$ & Nicosia & NF & 12 & 2008 & 2 & Apr, Oct \\
\hline 19 & Red Hawk & Leonidas & $\begin{array}{l}\text { Software } \\
\text { development }\end{array}$ & Limassol & FB & 35 & 1995 & 2 & Apr, Oct \\
\hline 20 & Tronics & Fanos & $\begin{array}{l}\text { Software } \\
\text { development }\end{array}$ & Limassol & FB & 18 & 2006 & 2 & May, Nov \\
\hline 21 & Beta Inc & Demos & $\begin{array}{l}\text { Digital design } \\
\text { and website } \\
\text { development }\end{array}$ & Limassol & NF & 8 & 2010 & 2 & May, Dec \\
\hline 22 & $\begin{array}{l}\text { Blueberry } \\
\text { Estate }\end{array}$ & Thanasis & Real estate & Pafos & NF & 16 & 2008 & 2 & May, Nov \\
\hline 23 & Rythmic & Spiros & $\begin{array}{l}\text { Group of } \\
\text { restaurants }\end{array}$ & Nicosia & NF & 35 & 2009 & 2 & Apr, Oct \\
\hline 24 & Square café & Katerina & Cafe & Larnaca & FB & 14 & 1993 & 2 & May, Nov \\
\hline
\end{tabular}


Table.1 (continued)

\begin{tabular}{|c|c|c|c|c|c|c|c|c|c|}
\hline $\mathrm{N}$. & $\begin{array}{l}\text { Company pseu- } \\
\text { donym }\end{array}$ & $\begin{array}{l}\text { Owner- } \\
\text { manager } \\
\text { pseudonym }\end{array}$ & $\begin{array}{l}\text { Industry/activ- } \\
\text { ity }\end{array}$ & $\begin{array}{l}\text { Business } \\
\text { location } \\
\text { (region) }\end{array}$ & $\begin{array}{l}\text { Family busi- } \\
\text { ness (FB)/non- } \\
\text { family business } \\
(\mathrm{NF})^{\mathrm{i}}\end{array}$ & $\begin{array}{l}\text { Size - \# } \\
\text { employ- } \\
\text { ees }\end{array}$ & $\begin{array}{l}\text { Year of } \\
\text { establish- } \\
\text { ment }\end{array}$ & $\begin{array}{l}\# \text { of } \\
\text { inter- } \\
\text { views }\end{array}$ & $\begin{array}{l}\text { Interview } \\
\text { periods } \\
(2020)\end{array}$ \\
\hline 25 & Sunblock & Periklis & $\begin{array}{l}\text { Shading } \\
\text { systems } \\
\text { Production } \\
\text { and sales }\end{array}$ & Nicosia & FB & 44 & 1977 & 2 & May, Nov \\
\hline 26 & Constructia & Sokratis & $\begin{array}{l}\text { Construction } \\
\text { and develop- } \\
\text { ment }\end{array}$ & Limassol & NF & 48 & 2010 & 2 & May, Nov \\
\hline 27 & Smart Kids & Theodora & Nursery school & Pafos & FB & 13 & 1983 & 2 & Apr, Oct \\
\hline 28 & Bistro Chefs & Antonia & Cafe & Nicosia & FB & 12 & 2003 & 2 & May, Dec \\
\hline 29 & Bar 99 & Nakis & Bar & Limassol & FB & 20 & 2005 & 2 & Apr, Oct \\
\hline 30 & Medi-Aid & Elpida & Medical centre & Nicosia & NF & 25 & 2007 & 2 & May, Dec \\
\hline 31 & $\begin{array}{l}\text { Bright Acad- } \\
\text { emy }\end{array}$ & Kyriaki & $\begin{array}{l}\text { Primary and } \\
\text { secondary } \\
\text { school }\end{array}$ & Pafos & FB & 46 & 1992 & 2 & May, Dec \\
\hline 32 & Vivento & Nefeli & $\begin{array}{l}\text { Venue and } \\
\text { catering for } \\
\text { special events }\end{array}$ & Limassol & FB & 11 & 2008 & 2 & May, Nov \\
\hline 33 & People First & Alexandros & $\begin{array}{l}\text { Job recruiting } \\
\text { agency }\end{array}$ & Nicosia & FB & 10 & 2006 & 2 & Apr, Oct \\
\hline 34 & Big Orange & Zoe & $\begin{array}{l}\text { Fashion bou- } \\
\text { tique }\end{array}$ & Famagusta & FB & 9 & 1999 & 2 & Apr, Oct \\
\hline 35 & Relax & Iasonas & $\begin{array}{l}\text { Wellness and } \\
\text { Spa }\end{array}$ & Limassol & NF & 37 & 2009 & 2 & May, Nov \\
\hline
\end{tabular}

${ }^{\mathrm{i}}$ Family business is defined as a business owned and/or managed by members of the founding family, and there is an intent to transfer or an actual generational movement of the business (Chua, Chrisman, \& Sharma, 1999; Heck \& Trent, 1999).

and changes made because of the pandemic, as well as their assessments of their businesses' current and future-post-pandemic-actions.

Two of the authors were involved in conducting the interviews, which were held via video link (Grinevich et al., 2019). Each interview was recorded and professionally transcribed verbatim in Greek to ensure its validity and reliability (Theodoraki et al., 2018; Grinevich, et al., 2019). The interview transcripts took up an average of 17 (session 1) and 30 (session 2) double-spaced pages each and over 1,600 pages overall. The interview transcripts were then translated to English using a common back-translation process (Harbi, Thursfield, \& Bright, 2017). Following Hollensbe et al. (2008), the data collection and analysis were conducted at the same time-we analysed the interviews conducted during session 1 before conducting the session 2 ones. This procedure gave us a chance to recognize the need for additional questions aimed at better comprehending the codes emerging in the analysis process and the flexibility to gather data more pertinent to any nascent concepts and emergent and interesting leads and relationships.

\subsection{Data analysis}

Our study was guided by the Gioia Methodology (Gioia et al., 2013), which has been employed by past studies taking an abductive research approach (e.g. Christou, Hadjielias, \& Farmaki, 2019; Glyptis et al., 2021). Under an abductive logic, the data analysis develops new theory through an iterative 'back and forth' process between the data and the literature (Dubois \& Gadde, 2002). Drawing on best practice, we performed the data analysis through consensual coding (Goffin \& Koners, 2011; Pan, Maclaurin, \& Crotts, 2007) between two research team members following the three coding stages 
prescribed by the Gioia Methodology (Gioia et al., 2013). During the first stage, the two researchers separately carried out an open coding process aimed at capturing any emergent insights (Goffin \& Koners, 2011; Holton, 2007) while adhering to the informant terms (Gioia et al., 2013). During this stage, both authors separately analysed each interview transcript and produced their own lists of codes (until saturation) in relation to various chunks of text (e.g. phrases, sentences, words, or paragraphs) (Corbin \& Strauss, 2014). When this task was completed, the two researchers shared their lists of codes with the intention to discuss any discrepancies and reach a consensus on a common master coding list (Goffin \& Koners, 2011; Pan et al., 2007). For instance, the emergent first-order concepts (or codes), which had been agreed by the two coders during the first coding stage, involved the individual owner-manager's 'negative emotions and negative psychology', 'difficulties to cope', and 'emotional and psychological breakdown', which had stemmed from their exposure to the COVID-19 pandemic conditions (see Fig. 1 for the full list of first-order concepts or codes).

During the second stage, the codes in the master list were grouped-based on similarities in terms of meanings and topics (Holton, 2007)—in order to develop second-order categories (Gioia et al., 2013). The researchers carried out this task separately, reducing the first-order concepts to a smaller number of categories (Corbin \& Strauss, 2014). When this task was completed, the two researchers met to discuss the categories they had produced and any discrepancies with the intention to reach an agreement (Goffin \& Koners, 2011). The outcome was a mutually agreed list of 'second-order categories', which are presented in Fig. 1. For instance, the first-order concepts agreed upon by the coders featured the owner-managers' willingness to empathize with their employees and personalize their communication and attention towards them in the midst of the pandemic. Such codes included a 'higher sensitivity towards employees', 'taking time to talk to employees', 'personalized attention', and 'efforts to help employees to overcome any personal problems'; these were brought

\section{1st Order Concepts}

\begin{tabular}{|c|}
\hline $\begin{array}{l}\text { Negative emotions and negative psychology (e.g. stress, } \\
\text { nervousness); difficulties to cope; emotional and psychological } \\
\text { breakdown; disruption of personal harmony and well-being }\end{array}$ \\
\hline $\begin{array}{c}\text { Optimistic outlook; Confidence that problems can be solved; } \\
\text { patiently monitor conditions; flexibility to solve personal } \\
\text { disruptions }\end{array}$ \\
\hline $\begin{array}{l}\text { Personal experiences feed reflection; Self-reflection on pandemic } \\
\text { conditions; Time to think; Ability to restore well-being disruptions }\end{array}$ \\
\hline $\begin{array}{c}\text { Higher sensitivity towards employees; Devote more time to talk to } \\
\text { employees; Personalized attention; Efforts to help employees to } \\
\text { overcome personal problems; }\end{array}$ \\
\hline $\begin{array}{l}\text { Alertness for entrepreneurial opportunities to renew the business; } \\
\text { monitoring the market for gaps; taking advantage of lockdowns to } \\
\text { think new ideas to improve business }\end{array}$ \\
\hline $\begin{array}{l}\text { Worries that employees may develop well-being problems as the } \\
\text { pandemic progresses; worries about the future of the business; } \\
\text { desire to monitor the workplace for any signs of psycho-emotional } \\
\text { problems within employees; thoughts how to anticipate future }\end{array}$ \\
\hline $\begin{array}{l}\text { Realization of stewardship role in the firm; realization of role } \\
\text { played in making decisions in the midst of the pandemic; } \\
\text { attachment to the business }\end{array}$ \\
\hline $\begin{array}{l}\text { Open discussions to resolve pandemic obstacles at work; Collective } \\
\text { decisions; Improvement of collective spirit at work; } \\
\text { Communication with employees sustains harmony }\end{array}$ \\
\hline $\begin{array}{l}\text { Monitoring the pandemic conditions; Swift implementation of } \\
\text { future projects; Flexibility to change structures and allow remote } \\
\text { work; Owner-manager's alertness and swift decisions for firm } \\
\text { adaptation }\end{array}$ \\
\hline $\begin{array}{l}\text { Mobilization of resources from controlling family to the firm; } \\
\text { Owner-managers request resources from immediate family; } \\
\text { Stewardship enhances reliance on family for support }\end{array}$ \\
\hline
\end{tabular}

Fig. 1 Data structure 2nd Order Categories

Aggregate Dimensions

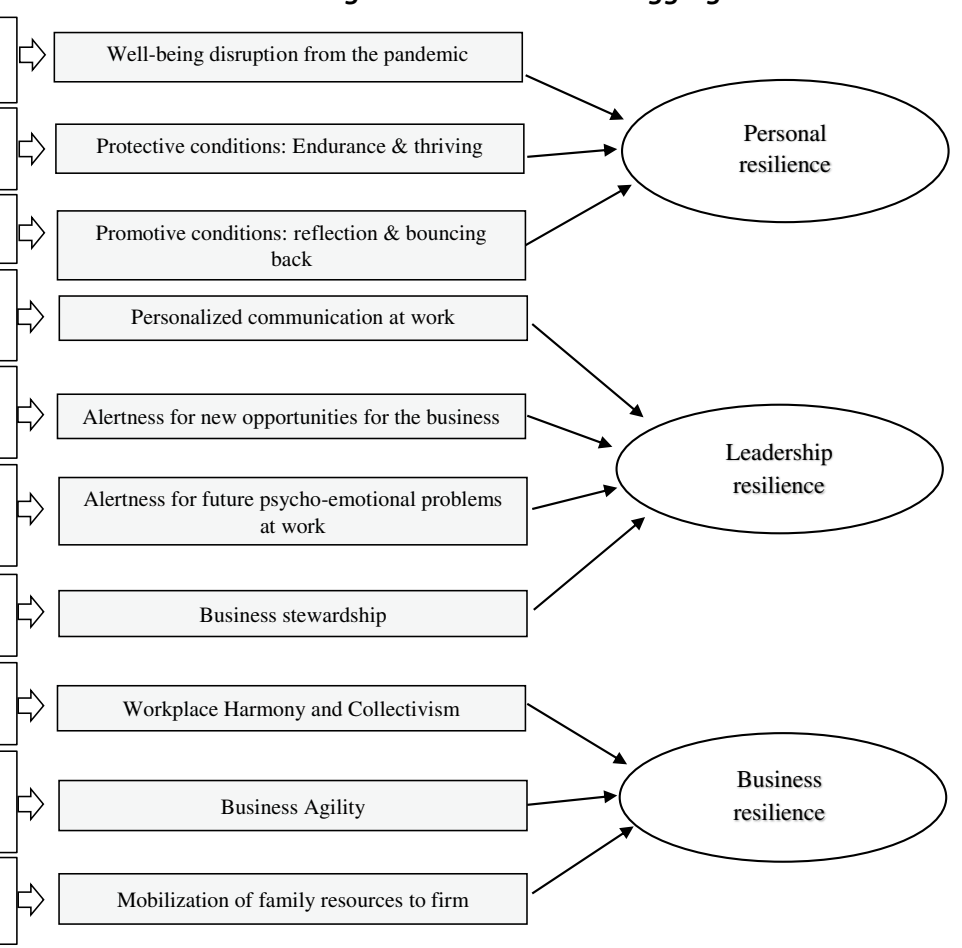


together under a second-order category that we labelled 'personalized communication' (see Fig. 1 for the full list of the second-order categories and their links to the first-order concepts).

While reaching a consensus on the 'second-order categories' during the second analytical stage, the two authors jointly engaged in a process whereby the second-order categories were compared with the extant literature on resilience and other relevant topics. This was done to determine which categories represented any existing concepts and which novel ones (Gioia et al., 2013; Sillince et al., 2012). During this process, any emergent categories that reflected concepts that already existed in the literature were adjusted to align their labels with the terms used in the literature. For instance, when grouping the first-order concepts that related to an owner-manager's optimistic outlook, confidence, and flexibility in solving personal disruption, the two coders agreed that these jointly described the 'protective' dimension of psychological resilience (Fletcher \& Sarkar, 2013) and therefore determined to label this category accordingly. This back-and-forth process between the data and the literature enabled the coders to discuss and better understand the connections and relationships between emergent categories. This process was important as it enabled the distillation of the second-order categories into fewer aggregated dimensions during the third stage of analysis (Gioia et al., 2013). For instance, the two coders agreed that the second-order themes 'personalized communication', 'alertness', 'stewardship', and 'person-role reflection' referred to essential aspects of the owner-managers' ability to act as leaders in the workplace and support their personnel and organizations in response to the pandemic. Consequently, they grouped these leadership qualities under a single aggregated dimension they labelled 'leadership resilience' (see Fig. 1 for the full list of aggregate dimensions and their links to second-order categories).

Our intention was to create a conceptual diagram capable of depicting the emergent relationships between the existing and nascent concepts (Gioia et al., 2013) and suited to explain the ways in which the owner-managers' psychological resilience had been influencing their small firms' resilience in the context of the COVID-19 pandemic.

\section{Findings}

Our study yielded evidence on the unprecedented challenges to owner-managers and their businesses brought by the COVID-19 pandemic. Our findings illustrate the influences found at the person-roleorganization nexus, shedding light on the ways in which psychological resilience-at the individual owner-manager level of analysis-fosters the resilience of small businesses within the context of the COVID-19 pandemic. The sections that follow explain how, through their personal and business role capacities, individual owner-managers embark on actions which facilitate the resilience of small businesses.

\subsection{The owner-managers' personal resilience in the midst of the pandemic}

The analysis highlighted that COVID-19 was affecting the personal lives and well-being of many small business owner-managers. One respondent indicated how the pandemic conditions and restrictions were influencing her personal life and personal routines: 'Psychologically, I had an issue during the first lockdown; I had to limit my personal activities, such as going out at night jogging or meeting with friends.' [Nefeli, Vivento, Nov 2020].

Consequently, a facet of personal resilience appears to be driven by the ability of an owner-manager to bounce back, restoring the personal wellbeing disrupted by the pandemic. As one participant highlighted, while COVID-19 had initially disrupted his personal life, he had managed to bounce back as an individual and restore his well-being: 'When I started to really realize where this situation was heading, I was knocked over. I needed some time to weigh up the situation, to get used to the change. However, I managed to get over it and regain my strength.' [Nakis, Bar 99, Oct 2020].

Nevertheless, some owner-managers affirmed that their personal conditions had remained largely unaltered or that they had even gained new strength and purpose in the midst of the pandemic. This leads to a second facet of personal resilience in the form of the ability to endure or even thrive under negative pandemic conditions. A participant stated: 
I am an optimist and, certainly, being optimistic that things will improve helps you deal better with any negative situations such as those that COVID has brought to us. It gives me more endurance to deal with problems. [Andreas, Arrow Consultants, Oct 2020]

Our findings suggest that each facet of personal resilience (i.e. bouncing back or endure) draws on a diverse path and is shaped by different conditions. We refer to these two different facets as type 1 and type 2 personal resilience, respectively. For each type, we then distinguish between promotive and protective conditions (Fletcher \& Sarkar, 2013). Promotive conditions are those individual factors that had shaped an owner-manager's ability to bounce back (Fletcher $\&$ Sarkar, 2013) and restore any personal well-being disrupted by the pandemic. A core promotive condition emerging from our findings is an owner-manager's ability to self-reflect. Protective factors are those that had enabled an owner-manager to endure or even thrive in the midst of the pandemic (Fletcher $\&$ Sarkar, 2013). The protective factors that emerged in our findings include an owner-manager's optimism, readiness, and forward-looking mentality. Table 2 illustrates the type of personal resilience characterizing each research participant; in particular, 19 of our participant owner-managers indicated an ability to bounce back from personal disruption (type 1), while 16 mentioned that they had remained largely positive and forward-looking, which had kept them going despite the negative environmental conditions (type 2).

Type 1 personal resilience was related to those sample owner-managers that had experienced disruption to their well-being as a result of the pandemic. One highlighted that the pandemic had increased her levels of stress and sadness and had influenced her psychologically as an individual: 'When the lockdown measures were put in effect, I had a major crisis. I was stressed, crying, I was feeling very nervous. I could not breathe. It really brought me down.' [Maria, Bella Me, Nov 2020].

As Table 2 illustrates, type 1 personal resilience had pertained largely to the owner-managers of those enterprises that had been forced to remain closed for significant lengths of time during the pandemic; for instance, firms providing close contact services such as hairdressing salons, wellness and spas, and personal care salons, which had been forced to suspend their operations during the first (23 March to 21 May 2020) and second regional (Limassol and Paphos) (12 to 30 November 2020) and national (30 November 2020 to 31 January 2021) lockdowns. The findings suggest that the suspensions of operations that had affected certain companies had exerted great pressure on owner-managers, subjecting a significant number of them to personal well-being disruption, either emotional or psychological. As one respondent who ran a hairdressing salon explained, the temporary closure of his business was a factor that had diminished his personal well-being: 'I am very active. I cannot stay grounded at home. I go out and do things. The pandemic has influenced my daily life [ ...] Not being able to be at work made things even worse for me.' [Giorgos, X-Style, May 2020].

Concerning the owner-managers endowed with type 1 personal resilience, our findings suggest that personal reflection had become an essential mechanism in the restoration of these individuals' personal well-being. Specifically, their ability to bounce back from the disruption caused by the pandemic was rooted in a self-reflective process that had enabled them to draw on the situation and past life events and experiences to overcome their personal well-being disruption.

I did what I am accustomed to doing. I acted patiently, I picked up my pieces from this situation [the COVID-19 pandemic], which definitely influenced me negatively. I wished to put the puzzle back together to see a clear picture which would take me to the next phase of my life, so I could move on. In such situations, it helps me to reflect on my past life-changing experiences of death and suffering. [Theodora, Smart Kids, Oct 2020]

Type 2 personal resilience had pertained to those owner-managers who had remained optimistic and forward-looking during the pandemic. Two of them explained that they had maintained an optimistic outlook and self-efficacy, which had helped them to flexibly and swiftly adapt to the pandemic conditions, and thus to endure:

I got used to it [the pandemic]. I see myself as an optimist and a problem solver. I adapted quickly. [Demetris, Futures, May 2020] 
Table.2 Resilient conditions exhibited by owner-managers

\begin{tabular}{|c|c|c|c|c|c|c|}
\hline \multirow{2}{*}{$\begin{array}{l}\text { Operational status } \\
\text { during COVID-19 }\end{array}$} & \multirow{2}{*}{$\begin{array}{l}\text { Owner-manager } \\
\text { (business) }\end{array}$} & \multicolumn{2}{|l|}{ Personal resilience } & \multicolumn{3}{|c|}{ Role resilience } \\
\hline & & $\begin{array}{l}\text { Type 1: Promotive } \\
\text { conditions; bounc- } \\
\text { ing back ability }\end{array}$ & $\begin{array}{l}\text { Type } 2 \text { : Protec- } \\
\text { tive conditions; } \\
\text { endurance/thriv- } \\
\text { ing ability }\end{array}$ & $\begin{array}{l}\text { Communi- } \\
\text { cation }\end{array}$ & Alertness & Stewardship \\
\hline
\end{tabular}

\begin{tabular}{|c|c|c|c|c|c|c|}
\hline \multirow{14}{*}{$\begin{array}{l}\text { Businesses remain- } \\
\text { ing closed for } \\
\text { significant lengths } \\
\text { of time during the } \\
\text { pandemic }\end{array}$} & Maria (Bella Me) & $\sqrt{ }$ & & & $\sqrt{ }$ & \\
\hline & Stathis (Gourmet AA)* & & $\sqrt{ }$ & & $\sqrt{ }$ & $\sqrt{ }$ \\
\hline & Giorgos $(X-S t y l e) *$ & $\sqrt{ }$ & & $\sqrt{ }$ & & \\
\hline & Eleni (Bean café) * & $\sqrt{ }$ & & $\sqrt{ }$ & & \\
\hline & $\begin{array}{l}\text { Evgenia (Muscle } \\
\text { Universe) }\end{array}$ & $\sqrt{ }$ & & & $\sqrt{ }$ & \\
\hline & Spiros (Rythmic) & $\sqrt{ }$ & & & $\sqrt{ }$ & \\
\hline & Katerina (Square café) * & $\sqrt{ }$ & & $\sqrt{ }$ & & \\
\hline & Theodora (Smart Kids) * & $\sqrt{ }$ & & $\sqrt{ }$ & & $\sqrt{ }$ \\
\hline & Antonia (Bistro Chefs)* & $\sqrt{ }$ & & & & $\sqrt{ }$ \\
\hline & Nakis (Bar 99)* & $\sqrt{ }$ & & $\sqrt{ }$ & & \\
\hline & $\begin{array}{l}\text { Kyriaki (Bright Acad- } \\
\text { emy)* }\end{array}$ & & $\sqrt{ }$ & $\sqrt{ }$ & $\sqrt{ }$ & \\
\hline & Nefeli (Vivento)* & $\sqrt{ }$ & & & & $\sqrt{ }$ \\
\hline & Zoe (Big Orange)* & & $\sqrt{ }$ & & $\sqrt{ }$ & $\sqrt{ }$ \\
\hline & Iasonas (Relax) & $\sqrt{ }$ & & $\sqrt{ }$ & & \\
\hline \multirow{21}{*}{$\begin{array}{l}\text { Businesses operat- } \\
\text { ing with restric- } \\
\text { tions during the } \\
\text { pandemic }\end{array}$} & $\begin{array}{l}\text { Andreas (Arrow } \\
\text { Consultants) }\end{array}$ & & $\sqrt{ }$ & & $\sqrt{ }$ & \\
\hline & Nikos (ReMark) & & $\sqrt{ }$ & $\sqrt{ }$ & & \\
\hline & Costas (Excelsior) & & $\sqrt{ }$ & $\sqrt{ }$ & & \\
\hline & Petros (e-Masters)* & $\sqrt{ }$ & & & $\sqrt{ }$ & $\sqrt{ }$ \\
\hline & Stelios (Sweet Ice) & $\sqrt{ }$ & & & $\sqrt{ }$ & \\
\hline & Lakis (TRC Audit)* & $\sqrt{ }$ & & $\sqrt{ }$ & & $\sqrt{ }$ \\
\hline & Pavlos (Blue Bear) & & $\sqrt{ }$ & $\sqrt{ }$ & & \\
\hline & Kyriakos (Guru media) & & $\sqrt{ }$ & $\sqrt{ }$ & & \\
\hline & Anna (QualiTrade)* & & $\sqrt{ }$ & & & $\sqrt{ }$ \\
\hline & Xenios (Data Stars)* & & $\sqrt{ }$ & $\sqrt{ }$ & & \\
\hline & Demetris (Futures)* & & $\sqrt{ }$ & & $\sqrt{ }$ & $\sqrt{ }$ \\
\hline & Christos (Physio Clinic)* & $\sqrt{ }$ & & $\sqrt{ }$ & & \\
\hline & Chara (Business Serve) & $\sqrt{ }$ & & & $\sqrt{ }$ & $\sqrt{ }$ \\
\hline & Leonidas (Red Hawk)* & & $\sqrt{ }$ & & $\sqrt{ }$ & \\
\hline & Fanos (Tronics)* & & $\sqrt{ }$ & $\sqrt{ }$ & & $\sqrt{ }$ \\
\hline & Demos (Beta Inc) & $\sqrt{ }$ & & & $\sqrt{ }$ & \\
\hline & Thanasis (Blueberry Estate) & & $\sqrt{ }$ & $\sqrt{ }$ & $\sqrt{ }$ & \\
\hline & Periklis (Sunblock)* & $\sqrt{ }$ & & & & $\sqrt{ }$ \\
\hline & Sokratis (Constructia) & & $\sqrt{ }$ & $\sqrt{ }$ & & \\
\hline & Elpida (Medi-Aid) & $\sqrt{ }$ & & & $\sqrt{ }$ & \\
\hline & Alexandros (People First)* & & $\sqrt{ }$ & & $\sqrt{ }$ & $\sqrt{ }$ \\
\hline
\end{tabular}

$\sqrt{ }$ Owner-manager highlighting action/ability/state

*Family Businesses

(Adapted from Scheidgen, 2021, p. 64) 
I am the kind of person that doesn't see the glass half empty or half full, but almost full. So, with this attitude, the A to $\mathrm{Z}$ is to have your patience and your optimism so you can keep a clear mind to see how things unfold and to act when needed. I am not a person that is panicked easily and loses hope. [Leonidas, Red Hawk, Apr 2020]

Another form of endurance emerged through the readiness of certain owner-managers to deal with the changing circumstances. For instance, there were participants, accustomed to work frequently from home, who recalled that the pandemic measures had not affected them to any significant degree: 'Ok, I was accustomed working from home before the pandemic. So, the lockdown did not affect me that much.' [Fanos, Tronics, Nov 2020].

As Table 2 illustrates, type 2 had largely been related to owner-managers from those firms that had remained partially operational (with certain restrictions) or that had been able to continue working from home throughout the pandemic (e.g. audit offices, consultancy firms, IT companies, consultants). This indicates that the avoidance of complete closure may have played a significant role in the positive mindsets of these owner-managers. As one respondent explained, the fact that his business had remained operational during the pandemic, albeit with restrictions, had been a reason to remain generally optimistic: 'Personally, it helped me that I could keep going to work or at least doing work from home. It kept my thoughts away from the reality of the pandemic, and generally helped me to remain positive.' [Sokratis, Constructia, Nov 2020].

For some of these type 2 owner-managers, the pandemic had not been a matter of enduring but an opportunity to improve and develop at the personal level. One interviewee explained that the pandemic had helped him to get to become better acquainted with digital technology, while another highlighted that the circumstances had given him the opportunity to strike a better balance between work and family life:

Let's look at the bright side of the pandemic. It pushed us to use technologies and learn new things we otherwise would not. I got to know Zoom! [smiling] [Pavlos, Blue Bear, Dec 2020]
Having the opportunity to work from home was healthy for me. While working, I could also spend more time with my wife and kids. It helped me to shape a healthier lifestyle and balance between work and family. I intend to keep it this way. [Fanos, Tronics, Nov 2020]

Our findings build on previous work conducted on the protective-promotive nexus of individual resilience (Fletcher \& Sarkar, 2013). We identified how certain owner-managers' protective traits-such as confidence, self-efficacy, and positive emotions ( $\mathrm{Gu}$ \& Day, 2007; Tugade \& Fredrickson, 2004)—had enabled them to endure or even evolve under adverse conditions. Furthermore, our findings highlight the role played by promotive conditions such as selfreflection in enabling resilient individuals to bounce back from hardships (Crane et al., 2020; Fletcher \& Sarkar, 2013), and specifically the disruption to individual well-being linked to the COVID-19 pandemic (Brand, Timme, \& Nosrat, 2020). Our study is nevertheless the first to provide research on owner-managers within small businesses with a resilience trait component that had hitherto been missing from the small business literature. At the same time, while our findings echo the reflective component of individual resilience (Flach, 1988; Moenkemeyer, Hoegl, \& Weiss, 2012), they shed more light on the self-reflection rooted in this process that enables individual owner-managers to bounce-back from disruptive life events.

\subsection{Leadership resilience driven by personal resilience}

The analysis highlights that the COVID-19 pandemic had affected the (leadership) role of our participating owner-managers in their respective businesses. Particularly, our findings suggest that the pandemic had led to changes or adjustments in our sample ownermanagers' leadership capacity in three areas: (a) communication, (b) alertness, and (c) stewardship. Our interviewees highlighted that such changes had made them more resilient as leaders, and consequently more able to exercise leadership in the midst of the pandemic. Table 2 illustrates the areas of leadership in which each research participant indicated an adjustment/improvement. As Table 2 shows, 17 of our interviewed owner-managers indicated an adjustment 
in the way they communicated with their employees, 16 mentioned that they had become more alerted to opportunities and risks, while 13 had experienced an enhancement in their stewardship behaviours towards their firms. As portrayed in this table, certain research participants highlighted changes in more than one leadership areas (for instance, a combination of adjustments in relation to communication and alertness). As indicated in Table 2, the vast majority of the owner-managers who highlighted adjustments in relation to their stewardship towards the firm were primarily from family businesses.

Our findings suggest that, in the context of the COVID-19 pandemic, an owner-manager's personal resilience becomes an antecedent of leadership resilience. In other words, the ability of owner-managers to bounce back and restore their personal well-being or their enduring ability to withstand any disruption to it was underpinning the adjustments or changes made to their leadership capacity. Table 3 indicates the way in which each type of personal resilience (types 1 and 2) underpins leadership role resilience in the areas of communication, alertness, and stewardship. Concerning 'communication', our sample owner-managers acknowledged that the pandemic had sensitised them to the human aspect in the workplace, causing them to invest more in communicating with employees. For many of our research participants, individualized communication had become a new norm, as they believed that their employees deserved personalized attention in order to overcome the social, psychological, and other personal issues caused by the pandemic. One respondent exemplified this:

I realized that, with every person, I have to communicate differently. This is new for me, but important. It is different for a person working from an apartment with two children, different for a person who is working from home alone and feels lonely. Every person is facing different issues during the COVID pandemic. So, I have noticed that it works through communication. [Costas, Excelsior, Oct 2020]

Our findings highlight that the ability to engage as a leader in close, personalized communication with employees had been shaped by the personal resilience of the individual owner-managers in the midst of the pandemic. Yet, the way and logic whereby each owner-manager facilitated personalized communication in the workplace depended on her/his type of personal resilience. As illustrated in Table 3, type 1 individuals who had bounced back from well-being disruption had drawn on 'empathy' and 'sensitivity' to engage in one-to-one communication with their employees in order to understand their problems and concerns and had acted accordingly to support them. Consequently, while type 1 owner-managers had been changing the way they communicated with their employees in the workplace, this transformation had been largely emotion-driven. One respondent exemplified this:

Table.3 Personal-role resilience nexus

\begin{tabular}{|c|c|c|c|}
\hline \multirow[t]{2}{*}{ Personal resilience } & \multicolumn{3}{|c|}{ Role resilience } \\
\hline & Personalized communication & Alertness & Stewardship \\
\hline $\begin{array}{l}\text { Type 1: Promo- } \\
\text { tive conditions; } \\
\text { bouncing back } \\
\text { ability }\end{array}$ & $\begin{array}{l}\text { Owner-managers become more } \\
\text { empathetic and sensitive to the } \\
\text { individual needs and problems of } \\
\text { each employee, understand better } \\
\text { the position of employees. }\end{array}$ & $\begin{array}{l}\text { Empathy and sensitivity incorpo- } \\
\text { rated into an alertness for future } \\
\text { psycho-emotional problems at } \\
\text { work. }\end{array}$ & $\begin{array}{l}\text { Negative experience and reflection } \\
\text { on the pandemic, makes owner- } \\
\text { managers more sensitive towards } \\
\text { the firm, having a pressure to act } \\
\text { as stewards to 'serve and protect' } \\
\text { it during harsh conditions. }\end{array}$ \\
\hline $\begin{array}{l}\text { Type } 2 \text { : Protec- } \\
\text { tive conditions; } \\
\text { endurance/thriv- } \\
\text { ing ability }\end{array}$ & $\begin{array}{l}\text { Infusing people in the workplace } \\
\text { with optimism and confidence. } \\
\text { Owner-managers present them- } \\
\text { selves as a 'success' (behavioural) } \\
\text { case to help employees achieve } \\
\text { balance. }\end{array}$ & $\begin{array}{l}\text { Confidence that the negative } \\
\text { pandemic conditions open up new } \\
\text { opportunities and possibilities for } \\
\text { the firm. } \\
\text { An optimistic leader faces less } \\
\text { ambiguity and worries and can } \\
\text { be more alerted for firm-specific } \\
\text { opportunities. }\end{array}$ & $\begin{array}{l}\text { Confidence in leading the firm, as a } \\
\text { proper steward, in the midst of the } \\
\text { pandemic. }\end{array}$ \\
\hline
\end{tabular}


Experiencing problems myself helped me to understand that there are many other people like me, my own people in the business, who experience similar issues and need to be supported. It was an emotional reaction; I felt their pain and I wanted to talk with each one of them to hear what they were going through and how I could help. [Theodora, Smart Kids, Oct 2020].

On the other hand, type 2 individuals who had endured or thrived in the midst of the pandemic disruption had drawn on 'optimism' and 'confidence' to boost the spirit of their employees in their one-toone interactions and communication with them (see Table 3). Our findings highlight that some ownermanagers underpinned by type 2 personal resilience had used their own 'success case' of enduring the pandemic to help their employees to overcome any personal and workplace struggles linked to it. Consequently, the type 2 owner-managers had adjusted their communication by drawing upon their traits linked to confidence and endurance:

I believe that certain attitudes that one has help during adverse conditions such as the pandemic. Personally, I dealt with the pandemic with lots of confidence, which was very effective in dealing with my people at work [...] I dealt with extreme communication with them. 'How are you?', 'How is it going?', 'What is worrying you?' We can discuss it and re-discuss it with extreme communication. [Xenios, Data Stars, Oct 2020]

When my employees see that I am positive and this does not get me down, and we discuss things together, I transfer this positive spirit to them. Then, they will see me as an example and they will be influenced positively as well. [Nikos, ReMark, Oct 2020]

Alertness was another area in which our sample owner-managers had experienced adjustments due to the pandemic. Our findings suggest that, as a result of the pandemic, our participating owner-managers had become more alerted of two aspects: (a) any future psycho-emotional issues in the workplace and (b) any entrepreneurial opportunities to renew or expand their firms under changing conditions. Amongst the group that highlighted alertness as an area of adjustment (see Table 2), some owner-managers indicated that, as a result of the pandemic, they were worrying that their employees could develop psychological or wellbeing problems as the business progressed and that they thus needed to be in a position to swiftly spot, control, and reduce any such problems. One respondent mentioned:

I am mostly worried about any future serious psychological problems for the people at work. I am monitoring it. I haven't noticed anyone being especially sad or depressed but, should this situation lasts much longer, it will create problems for the psychological health of my employees. [Spiros, Rythmic, Oct 2020]

Another area of increased leadership alertness was related to entrepreneurial aspects. Our findings suggest an increased alertness of our sample owner-managers in regard to any opportunities that could help the firm to renew, expand, or minimize costs during the pandemic:

This crisis has caused me to monitor the market, the competition, and any new technologies more carefully in order to make any changes that could help my business to take advantage of some of these conditions. For example, in the past, I hadn't considered online sales. [Stathis, Gourmet AA, Nov 2020]

Our findings highlight that the nature of the adjustments made as a consequence of the alertness aspect of leadership had depended on each owner-manager's personal resilience type. As illustrated in Table 3, type 1 individuals (promotive; bouncing back) had drawn on 'empathy' and 'sensitivity' to become more alerted of any future psychological, emotional, or well-being disruption affecting their employees in the workplace. Consequently, the enhanced alertness of our sample type 1 owner-managers had been more emotion-driven. One interviewee exemplified this:

In facing the difficulties of the pandemic and getting through them, it also became clear to me that this was something important that I need to deal with in the workplace [...] Although it may not be apparent now, should this pandemic continue, it could put additional pressure on my employees. I need to be there for them, but adequately prepare to deal with it. [Maria, Bella Me, Nov 2020]

On the other hand, our sample type 2 owner-managers (protective; enduring), who were confident and 
optimistic, acknowledged that the pandemic could provide opportunities for their businesses and had therefore become more alerted of any entrepreneurial opportunities for firm growth or renewal. Therefore, our type 2 owner-managers exhibited an enhanced alertness, which is linked to their traits of confidence and tolerance of ambiguity. One of them highlighted:

This is my approach; I like this kind of challenges [the COVID-19 pandemic]. Despite how strange it may sound, I saw the COVID pandemic as an opportunity to do the things we were discussing in relation to the business. [Leonidas, Red Hawk, Apr 2020]

Increased stewardship of the business is a third area in which the research participants had experienced changes as part of their leadership in the firm. Our findings illustrate that COVID-19 pandemic had made certain owner-managers think more about their relationship with and responsibility towards their respective firms and strengthen their stewardship to help them under such adverse environmental conditions. One of the interviewees mentioned:

My thinking, my perceptions have changed due to the pandemic. I have become more aware of the responsibility that I have towards my business and that I have to act in good faith towards it. So, any decisions I make from this point onwards are definitely going to be influenced by this thinking.

[Lakis, TRC Audit, Oct 2020]

Our findings illustrate how the enhanced stewardship exhibited by our sample owner-managers as a result of the pandemic was underpinned differently by the two personal resilience types. As illustrated in Table 3, type 1 individuals (promotive; bouncing back) had drawn upon the 'empathy' and 'sensitivity' they had developed as a consequence of their own negative experiences and reflective practices linked to the pandemic and felt the pressure to act better as stewards to 'serve and protect' their firm. Consequently, the stewardship attitudes re-shaped by our sample type 1 owner-managers were more emotion-driven. One of them exemplified this:

When the business was closed for a period due to the lockdown measures, I had lots of time to think. This period was important because it helped me to re-discover myself, to overcome my own worries, and to re-establish my bonds with the business. I made a lot of sacrifices to grow this firm, and it became clear that I needed to put more hours and effort to deal with the difficulties, with the lockdowns, with the reduced customers, with all the restrictions. [Nefeli, Vivento, Nov 2020]

Our sample type 2 owner-managers (protective; enduring), on the other hand, felt more confident in regard to driving their firms through the pandemic. Given the adverse conditions caused by the pandemic and their own personal endurance, they sensed that they could absorb the risks and identify solutions to help their business through enhanced stewardship. Consequently, the stewardship attitudes re-shaped by our sample type 2 owner-managers were more trait-driven (e.g. confidence, optimism). One such respondent indicated:

This situation [the pandemic] made me realize that the business depends on me and what my actual role towards this business is [...] I am a strong person, and the fact that this situation did not influence me negatively helped in focussing on the business with a clear mind. [Alexandros, People First, Oct 2020]

While previous work had largely treated leadership resilience as a metaphor (Gray, 2017), our study is the first to address the specific resilient competencies of leadership (i.e. personalized communication, alertness, and stewardship) and the ways in which they are used by owner-managers to address any disruption in the workplace. Further, our findings shed light on the relevance of the owner-managers' personal resilience in the practice of leadership in the midst of the COVID-19 pandemic. While leadership resilience has been viewed from an individual or psychological angle (Gray, 2017; Smith, 2015), the extant literature does not distinguish between the personal and (workplace) role capacities of the individual in examining resilience. Additionally, our findings provide insights into the path dependence of the owner-managers' leadership resilience, linking it to their personal resilience.

\subsection{From leadership resilience to business resilience}

Our findings highlight outcomes at the business level while linking leadership (role) resilience with business resilience. Our research participants articulated 
that, as a result of changing the practice of their leadership, they had noticed an adaptation of their businesses to the pandemic conditions.

It was important for me to realize that I needed to act to deal with the effects of the pandemic. When people see that their boss is positive and does not let things get him down, they will be influenced positively, and this will not disrupt our everyday activities. [Sokratis, Constructia, May 2020]

Our findings link the COVID-19 pandemic with business changes or developments in three core areas: (a) workplace harmony and collectivism, (b) business agility, and (c) resource mobilization for the firm. Our findings suggest that such changes had been essential in enhancing business resilience and thus equipping the business with the ability to bounce back or thrive in the midst of the negative effects caused by the pandemic. Each area of business resilience was identified as being underpinned by one or more leadership resilience capabilities (i.e. communication, alertness, or stewardship). Table 4 summarizes the findings at the nexus between leadership and business resilience.

Concerning 'harmony and collectivism', our sample owner-managers emphasized the significance of these outcomes during the pandemic, as they had helped to minimize any disruption in the functioning of the business. One respondent emphasized:

It [the pandemic] has brought us closer together. It has enabled us to discuss openly and to agree upon certain rules suited to keep our working schedule undisrupted and harmony in the business. Certainly, a positive aspect of this situation has been that it has helped to improve the collective spirit in the business. [Kyriakos, Guru Media, Oct 2020]

Our findings suggest that the (leadership) role of our sample owner-managers had been critical in keeping people calm in the workplace and in fostering collectivism at work during that strenuous and depressing period. Specifically, harmony and collectivism outcomes appeared to stem from the personalized communication that the owner-managers had begun to offer to their employees in response to the pandemic. Our findings highlight that, by communicating more closely and individually with their employees, our sample owner-managers had been able to make them feel safer and less threatened at work, which also strengthened harmony in the workplace. One interviewee highlighted:

I talked a lot with all my employees to ensure that they wouldn't be psychologically affected. This helped to minimize the negative emotions and pressures from the external environment and to keep people calm in the business. [Iasonas, Relax, May 2020].

Moreover, many of our sample owner-managers emphasized that the pandemic had caused their businesses to deal with the pressure linked to having to make changes to cope with the pandemic. Other interviewees mentioned that the pandemic had given them the opportunity to realize some ideas that they had had in mind to implement in the future. Altogether, our findings suggest that, in times of crisis, businesses may become more agile and thus able to respond faster to market opportunities, problems, or trends.

Some things are just excuses. When we say that the timing is not good, it needs a lot of time, and so on. You can do a lot of things that you have in your mind much earlier. This is what this crisis has taught us. It has forced our business to do things to survive, it has helped us to go online much faster than we ever thought we would. [Kyriaki, Bright Academy, May 2020]

We had this idea to develop a department for adult education, but we did not have the time to pursue it. The pandemic has been useful because it has given us the time to think more about this project and to make the decision to implement it. [Chara, Business Serve, Oct 2020]

Concerning agility, some participants also emphasized the flexibility of the business in terms of allowing people to work from home, acknowledging that certain people had good reason to not physically be in the workplace. Consequently, a second facet of agility that was mentioned was associated with a business's ability to facilitate any necessary changes in the structures and routines of work: 'Some people have needs and have to stay home; our business has become more flexible to cater for this request.' [Thanasis, Blueberry Estate, May 2020]. 


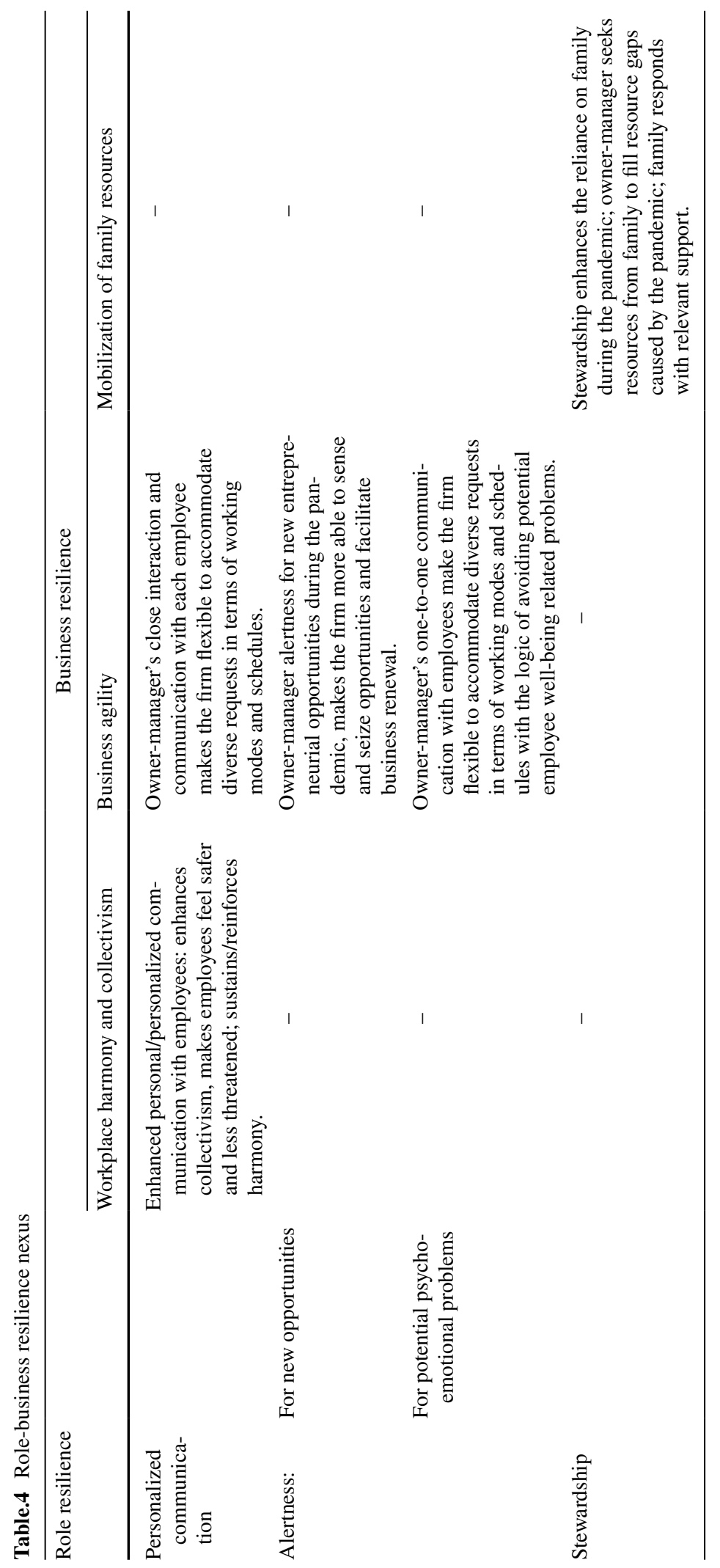


Our findings illustrate that the increased agility to facilitate business renewal had stemmed from our sample owner-managers' increased alertness for firm-specific opportunities, thus linking leadership resilience with business resilience. By becoming more alerted to changes in the business environment for potential threads or opportunities, our sample owner-managers had become more adept to making quick business decisions suited to adapt to such changes, thus reinforcing agility — and its associated outcomes-at the business level.

I was monitoring the situation in great detail from the start. The market, what the competition was doing, the news, the developments. Things progressed pretty fast, but I had to make swift decisions such as making our training academy completely virtual. We also assessed the market and realized an opportunity, and we are now entering the online food delivery market. [Demetris, Futures, Dec 2020]

At the same time, the agility suited to change work structures and routines appeared to stem from our sample owner-managers' increased personalized communication at work and alertness for potential future psycho-emotional issues at work. Our findings illustrate that those owner-managers who had been keen to engage in close conversations with their employees-while remaining vigilant to foresee any future well-being related issues that could affect them-would be swift in changing working structures, schedules, or routines. As highlighted by one respondent, acknowledging (through close discussions) the obstacles faced by his employees during the pandemic — and to avoid any additional negative effects on their well-being - he had taken the initiative to create a blended working structure suited to accommodate his employees' needs for either physical or virtual work:

The whole issue with COVID made me realise that we all are people, and that everyone thinks and behaves differently under different circumstances. Under such adverse conditions, I was able to become more familiar with the character, needs, and concerns of each of my employees. Some were afraid to leave the house; therefore, it would not have been good for them if I had put them on the frontline and expected them to perform under pressure. On the other hand, you see some that say 'Let's go for it'. Because I respect their concerns, and I want to see them all return back to work safe and happy very soon, I have introduced a blended working structure suited to also accommodate the requests of people who wish to work from home. [Demos, Beta Inc., Dec 2020]

A third business outcome concerns the mobilization of family resources, which is again connected to the changes occurring at the leadership level. Our findings illustrate that this outcome is associated with the resilient practices of owner-managers of family businesses (see also Table 1), whose role is important in facilitating the mobilization of resources from the (controlling) family to the business. Our research participants referred to external resources such as funds, free labour, and ideas being transferred from the family to the business in the midst of the pandemic. Our participants justified such transfers as essential to fill any resource gaps and solve any problems caused by the pandemic, such us financial injections aimed at sustaining the cash flow and operations, free labour to minimize costs, and ideas for improving or changing practices in order to cope with the new conditions.

We are very connected as a family. My father, who has retired, has been very stressed with this situation. He has helped us a lot by being in the shop every day since the very first day of the pandemic. He has also supported us financially, especially during the first lockdown, when our sales between March and May hit bottom. [Petros, e-Masters, Nov 2020]

Our findings provide links between the increased stewardship levels of our sample owner-managers and the external resource contributions made by the controlling families to their businesses. Our research participants explained that, due to being overwhelmed by their responsibilities towards their businesses, they had asked for the support of their immediate family circles. This had been done in order to gain access to any resources essential to keep the businesses going. A shift in the leadership resilience associated with enhanced stewardship had thus been crucial to the transfer of family resources to the firms:

During difficult times like these, the first people who come to your mind is your close family mem- 
bers. Here, this business is feeding four families. It also becomes a family concern. My husband and my parents may not be involved in the business, but they wish to provide ideas and solutions. The more I feel the responsibility to preserve the business, which was handed down to us by our parents, the more I wish to rely on my family for support. [Anna, QualiTrade, May 2020]

Our findings build on previous work on small business resilience (Ibora et al., 2019; Torres, Marshall, \& Sydnor, 2019) offering a contextualized understanding within the COVID-19 pandemic. While entrepreneurial agility (Chakravarty et al., 2013) and the mobilization of family social capital (Salvato \& Melin, 2008) had been identified as playing important roles during disruptive events, they had not been specifically researched for their merits in understanding business resilience. Further, workplace harmony and collectivism had hitherto been overlooked in research on business resilience. Overall, our findings offer a novel understanding of the ways in which specific business resilient actions are linked to specific resilience practices at the leadership level. For instance, how the reinforced leadership stewardship of the owner-managers of small family firms in the midst of the pandemic is facilitating the transfer of resources from the controlling family to the firm in order to fill any business resource gaps. Despite building on the path dependency of organizational resilience (Gittell et al., 2006; Ortiz-de-Mandojana \& Bansal, 2016), our findings offer a novel thematic or contextualized understanding of the interplay between leadership and organizational resilience in small businesses, which is essential in understanding the microfoundations of organizational resilience.

The section that follows discusses the findings in relation to the existing literature and highlights the key contributions to theory and literature stemming from our work.

\section{Discussion}

Our study provides evidence of the ways in which psychological resilience-at the individual ownermanager level of analysis-facilitates small business resilience within the context of the COVID-19 pandemic. We reveal a sequential process centred on owner-managers and on their abilities to build-up or strengthen any personal and leadership resilient capacities, which appear to be prerequisites for the establishment of resilient actions at the level of the small business. Fig. 2 depicts our findings.

In our study, 'personal resilience' is conceptualized as the owner-managers' ability to achieve a personal balance under adverse external conditions. Our findings extend the limited work on psychological resilience within small businesses (Chadwick \& Raver, 2020); it does so by shedding light on the ways in which owner-managers respond to complex or adverse conditions to achieve, first and foremost, a balance in their personal lives. To the best of our knowledge, ours is the first study to examine the

\section{PERSON}

PERSONAL RESILIENCE
ROLE

LEADERSHIP RESILIENCE
ORGANIZATION

BUSINESS RESILIENCE

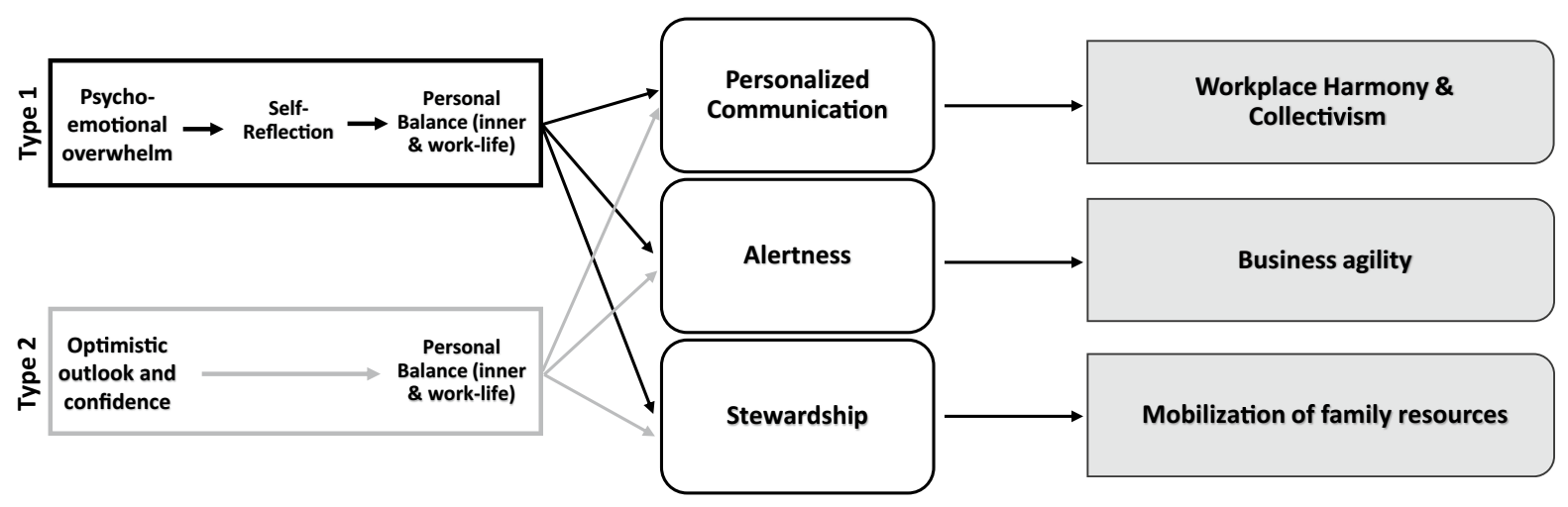

Fig. 2 Small business resilience at the person-role-organization nexus 
psychological resilience build-up of individual ownermanagers. Our findings distinguish between two types of personal resiliencies, depending on the dominance of promotive or protective conditions. Type 1 pertains to those owner-managers who have drawn on promotive conditions to reflect on their accumulated experiences and past life events to bounce back from the psycho-emotional distress caused by the pandemic. Conversely, type 2 includes those who have remained largely optimistic and forward-looking during the pandemic and have thus avoided any significant disruption to their personal balance.

In our study, 'leadership resilience' is linked to personal resilience. We conceptualized it as a rolespecific feature linked to the leadership role of the owner-manager. Our findings suggest that leadership resilience stems from an owner-manager's ability to respond to the pandemic conditions, first and foremost, at the personal level, where an inner and worklife balance is deemed essential. Previous work has mainly examined leadership resilience from a practical perspective (Gray, 2017; Smith, 2015), treating it mostly as a metaphor suited to emphasize the robust psychological qualities that leaders should maintain at the workplace to be able to effectively practice their role (Gray, 2017). Yet, we know little about the build-up or components of this type of resilience in an organizational context-specifically that of the small firm, where the leader-figure takes on the form of a dominant owner-manager (Gibson \& Cassar, 2005; Mc Cartan-Quinn \& Carson, 2003). Our study suggests that leadership resilience encompasses three major components: personalized communication, alertness, and stewardship. In our findings, personalized communication emerges as a key competency that enables owner-managers to psycho-emotionally converse with and support each individual in the workplace in light of the pandemic events. Alertness is a second leadership competency linked to an increased alertness to and monitoring of any potential psychological problems arising within the workplace. A second facet of this alertness is linked to any entrepreneurial opportunities for business change or expansion suited to take advantage of the new conditions or to alleviate any functional issues. Stewardship pertains to the enhanced acknowledgement, made by the owner-managers of small family firms, that they act as actual stewards of their firms and that the latter's survival is merely down to their own actions. Our findings highlight that each identified type of personal resilience exerts a different influence on leadership resilience in the areas of communication, alertness, and stewardship. For instance, type 1 owner-managers draw on 'empathy' and 'sensitivity' to engage in one-to-one communication with their employees in order to understand their problems and concerns; conversely, type 2 owner-managers draw on 'optimism' and 'confidence' to boost their employees' spirits.

In terms of business outcomes, our work illustrates that small businesses embark on pandemic-induced actions that are essential for their survival. These actions, which enhance 'small business resilience' under such extraordinary conditions, fall within three practical streams: 'workplace harmony and collectivism', 'business agility', and 'mobilization of family resources'. For each of these, our study provides linkages between the owner-managers' (i.e. leadership) resilience and that of their respective firms. Harmony comes as an enhancement and is essential during the pandemic because it hinders stressors from penetrating into the physical or virtual workplace and from negatively influencing the employees. Although workplace harmony has been linked to employee quality of life and productivity in the workplace (Chen et al., 2016), it has not hitherto been examined as a resilient action or as a component of a firm's resilient capacity build-up. In our study, collectivism takes on the form of those jointly agreed practices and actions that enhance unity within the workplace. As a feature of resilience, collectivism has been examined at the level of communities or regions to explain the joint practices undertaken by multiple stakeholders in the wake of major natural disasters such as tsunamis (Kayser, Wind, \& Shankar, 2008). Yet, we know little about the ways in which collectivism becomes instrumental in business resilience and thus in business survival under adverse external conditions. In our study, workplace harmony and collectivism stem from the owner-managers' capacity to personalize their communication approaches within their respective workplaces. These findings provide new knowledge on the (path) dependency of business resilience on leadership resilience, knowledge that has yet to be reflected in the literature on business resilience.

Further, our study identifies 'business agility' as a feature of small business resilience build-up in the midst of the COVID-19 pandemic. Business agility 
appears as a firm's ability to rapidly seize new opportunities or to swiftly implement any ideas planned for future development. Besides agility in entrepreneurialism, our study sheds light on a facet of agility linked to flexibility in reorganizing work to the end of meeting the diverse requests and needs of the workforce, such as being able to work from home during the pandemic. Whereas past work has identified different facets of agility such as supply chain flexibility (Gligor et al., 2019), operational agility (Akhtar et al., 2018), and strategic agility (Weber \& Tarba, 2014), our study relates more closely to the notion of strategic agility, which enables organizations to rapidly change direction and ways of organizing in response to environmental changes (Agarwal et al., 2007; Shams et al., 2021; Weber \& Tarba, 2014). Strategic agility works well in the presence of dynamic capabilities, which enable an organization or its managers to flexibly sense, seize, and reconfigure any resources needed by a firm to adapt in the midst of deep uncertainty (Teece, Pisano, \& Shuen, 1997; Teece, Peteraf, \& Leih, 2016). Despite being praised for its value during exogenous shocks (Chakravarty et al., 2013; Teece et al., 2016), strategic agility has not been sufficiently addressed in relation to small business resilience. While our study does not explicitly address the role played by dynamic capabilities in relation to business agility or resilience, it does hint at the fact that owner-managers may possess the relevant dynamic managerial capabilities (Helfat \& Martin, 2015) that make them flexible enough to sense and seize any ongoing growth opportunities and/or facilitate the organizational changes relevant to exogenous shocks. Further, the agility needed to accommodate employee working modes has not hitherto been reflected in the literature and appears to be a novel finding linked to the COVID-19 pandemic context. Additionally, our study provides novel evidence pertaining to the path dependency between business agility and alertness, as facets of business and leadership resilience, respectively.

In the literature, access to and use of family resources has been examined in the context of family social capital (Herrero \& Hughes, 2019; Salvato $\&$ Melin, 2008). Our findings indicate the importance of family members-who are external to a firm-in terms of filling any resource gaps. Past work illustrates that smaller firms are highly likely to be affected by resource gaps, such as financial ones, as a consequence of exogenous shocks (Owen et al., 2019). Family social capital is important for the survival of family-owned businesses under adverse conditions, as it enables the transfer of resources from family contacts external to the firm (Salvato \& Melin, 2008). While our study sheds light on the value of family social capital as a means to fill any resource gaps for a firm (Salvato \& Melin, 2008), it also illustrates the role played by owner-manager stewardship (as a facet of leadership capacity) in mobilizing this type of capital. Although stewardship has been linked with family social capital mobilization within family businesses (Bika \& Kalantaridis, 2019), the connection between these concepts has not been observed at the nexus between leadership and business resilience.

\subsection{Theoretical and empirical contributions}

Through this study, we contribute theoretically and empirically to the literatures on small business resilience and organizational resilience. First, we contribute theoretically by conceptualizing the links between personal, leadership (role), and organizational resilience in small businesses. The path dependency of organizational resilience, as a capability, has been highlighted in the literature (Gittell et al., 2006; Ortizde-Mandojana \& Bansal, 2016); however, the extant work has focused on the organizational level, examining the ways in which businesses develop such capability over time when faced with unforeseen circumstances (Ortiz-de-Mandojana \& Bansal, 2016). Our study conceptualizes organizational resilience as a path-dependent capability at the intersection between person, role, and business. It provides a bottomup theorization, placing the resilience of individual owner-managers (in relation to their personal and role capacities) as a key prerequisite for resilient-actions at the business level. This contribution provides a midrange theory suited to explain the micro-prerequisites of business resilience-specifically, the need for owner-managers to nurture resilience at the personal and leadership levels. Our mid-range theory also sheds light on the threads found at the nexus between leadership and organizational resilience, which justify organizational resilience actions (i.e. workplace harmony/ collectivism, business agility, resource mobilization to the firm) as a manifestation of specific leadership qualities (i.e. personalized communication, alertness, and stewardship) possessed by owner-managers. 
Second, by drawing on the concept of psychological resilience (Fletcher \& Sarkar, 2013; Kong et al., 2015), we introduce a novel psychological perspective to the study of organizational resilience. To examine resilience at the firm level, previous studies have drawn largely on organizational theories such as the resource-based view (Pal, Torstensson, \& Mattila, 2014), organizational social capital (Fandiño et al., 2019), and dynamic capabilities (Jiang et al., 2019). To the best of our knowledge, our study is the first to draw upon a psychological perspective to examine firm resilience. In doing so, we uncovered, within organizational resilience, essential micro-dynamics linked to the personal lives and leadership capacities of individual owner-managers that had hitherto been latent in the organizational resilience literature.

Third, we contribute theoretically to the small business resilience literature through context-based theorization. Our study contextualizes the individual-firm resilience nexus within the COVID-19 pandemic, shedding light on its resilience-specificities for individual owner-managers and small firms. It provides insights linked to the idiosyncrasies and dynamics of the COVID-19 pandemic, thus responding to the calls made to contextualize findings in order to better understand the influences and practices that lead to small business continuity (Zahra et al., 2014).

Fourth, we contribute empirically to the literature on small business resilience by generating new knowledge on the micro-underpinnings of small business resilience. These involve the personal qualities exhibited and reflections made by individual ownermanagers in the midst of the pandemic in order to bounce back or endure at the personal level and the ways in which personal resilience feeds leadership responses across a number of dimensions (i.e. communication, alertness, and stewardship) to facilitate business resilience. Although owner-managers are acknowledged for their centrality and pervasive roles in small businesses (Gibson \& Cassar, 2005; Mc Cartan-Quinn \& Carson, 2003), we know little about how their resilience can influence that of smaller firms.

Fifth, we respond to the calls made for research on organizational resilience at a multi-level unit of analysis (Santoro et al., 2021). We contribute methodologically to the organizational resilience literature by simultaneously focussing on the individual and organizational levels in order to examine small business resilience. The extant literature had hitherto largely drawn upon the firm level to examine resilience (e.g. Dahles \& Susilowati, 2015; Iborra et al., 2019), largely ignoring the role played by the individuals within organizations, which may be important in constructing resilient enterprises. Our multi-level consideration enables a shift beyond the current nondimensional understanding of resilience in organizations. Our study of resilience at both the individual and firm levels sheds light on the existence of two forms of resilience-i.e. individual (which can be further broken down into personal and leadership resilience) and firm resilience-which can set the grounds for future work drawing on the multiple forms of resilience found within organizational settings.

\subsection{Practical implications}

Our findings provide essential practical implications suited to help enhance the owner-manager and small business resiliencies in the face of exogenous crises such as the COVID-19 pandemic. First, we provide information on essential personal-level responses that can guide the leadership role of owner-managers in the midst of the continuing COVID-19 pandemic. For instance, our findings highlight the need for ownermanagers to strike an inner (psycho-emotional) balance and a personal work-life one before practicing leadership in the midst of the pandemic. Our findings illustrate that such balances are essential in assisting owner-managers in the practice of value-added leadership within a COVID-19-plagued world. Further, we highlight specific qualities - such as personalized communication, alertness, and stewardship-as essential for conducive leadership within the workplace. Business owners and/or managers could draw upon these areas in order to better contextualize their leadership approaches in the midst of the pandemic.

Second, given that, in times of crisis, smaller firms may face similar complexities and constraints, their owners-managers could benefit from forming communities of practice (Brown \& Duguid, 1998) or social networks (Carroll \& Teo, 1996) to navigate through the COVID-19 pandemic. Physical or virtual spaces could be used to bring together owner-managers to socialize and openly discuss their pandemic-related issues at both the management and business levels. Drawing upon the findings of our study, such communities or networks could help in the co-production 
of knowledge aimed at helping individual ownermanagers to enhance their personal, leadership, and business-specific resiliencies and understand the connections between them. For instance, knowledge co-production could centre on how managers might become more attentive and personalized in their communication with their employees in order to help their firms to preserve or enhance organizational harmony.

Third, given that exogenous crises, such as the COVID-19 pandemic, are particularly threatening to the survival of smaller firms, policymakers and small firm associations could also take note of our findings in order to enhance small business resilience. Adopting supply-side policies and increasing spending on training in order to improve the resilience skills of small business owner-managers would be useful. Small firm associations could also play an active role in designing and running training programmes targeted at owner-managers. Drawing upon the findings of our study, training programmes could be designed with the aim of enhancing both the owner-managers' personal and leadership resilience qualities, which are essential for small business resilience. Therefore, training may need to encompass modules drawing on both psychology and the business disciplines.

\subsection{Limitations and avenues for future research}

Our study is not free from limitations, but does provide opportunities for future work in the field of small business resilience. First, our study drew on a small sample, one not substantial enough to extract valid conclusions generalizable across small businesses. Consequently, future work could be based on larger samples and conduct survey-based quantitative investigations to the end of extracting more valid results. Future quantitative work could draw upon our findings, and particularly upon our conceptual model, to measure our emergent concepts and test the relationships we propose. Second, our study was carried out in a small-country context (i.e., Cyprus), which implies the presence of idiosyncrasies (e.g. culture and business practices) that may not be applicable in other contexts. Future qualitative work should be carried out in other contexts in order to enable the drawing of definite conclusions on the relevance of the person-role-organization nexus in studies on organizational resilience. Further, future work drawing upon cross-national studies and comparisons could provide an understanding of which micro-foundations, relations, and influences are relevant to the study of organizational resilience.

Third, our longitudinal study drew on carrying out same-sample interview sessions within a small timeframe (10 months) to examine the individualorganization resilience nexus in the context of the COVID-19 pandemic. This time horizon may not be substantial enough to draw valid conclusions, particularly on the path dependence of organizational resilience, which reflects a build-up of organizational capabilities over a long-term perspective (Gittell et al., 2006; Ortiz-de-Mandojana \& Bansal, 2016). Future longitudinal studies could look into individual-organization resilience over a longer time horizon and, should the circumstances permit, across different crises. This could yield a more holistic understanding of the shifts and developments found at both the individual and organizational levels, concerning the build-up of relevant resilience capacities.

Fourth, as not all small firms are owner-managed, our findings do not apply to those run by management teams or boards (e.g. Kollmann et al., 2017; Vyakarnam \& Handelberg, 2005). Future research could replicate our study or test our model by drawing on managerial teams within smaller firms. This could provide insights on managerial-team psychological resilience and on the ways in which this can influence business resilience.

Finally, our choice of a sample involving firms that had survived the COVID19 pandemic implied an underlying survivor bias; this involved a lack of insights from firms that had failed. The risk here is that survivor bias may have yielded an illusory relationship between variables (Kalnins, 2007). Future research could draw upon diverse samples or carry out various studies among survivor and failed firms to understand whether the underlying circumstances concerning resilient capabilities and processes are fundamentally different between the two samples.

\section{Conclusions}

Our study has examined the ways in which ownermanager resilience influences that of small firms. We provide insights into the micro-underpinnings of resilience within small firms, which are linked to the responses enacted and resilient qualities possessed by 
owner-managers at both the personal and leadership levels. While, by drawing on a psychological perspective, we provide a novel conceptualization of small business resilience at the person-role-organization nexus, our study is also the first to contextualize small firm resilience within the COVID-19 pandemic.

\section{Data availability Not applicable}

Code availability Not applicable.

\section{Declarations}

Conflict of interest The authors declare no competing interests.

\section{References}

Adekola, J., \& Clelland, D. (2020). Two sides of the same coin: Business resilience and community resilience. Journal of Contingencies and Crisis Management, 28(1), 50-60.

Agarwal, A., Shankar, R., \& Tiwari, M. K. (2007). Modeling agility of supply chain. Industrial Marketing Management, 36(4), 443-457. https://doi.org/10.1016/j.indma rman.2005.12.004.

Akhtar, P., Khan, Z., Tarba, S., \& Jayawickrama, U. (2018). The Internet of Things, dynamic data and information processing capabilities, and operational agility. Technological Forecasting and Social Change, 136, 307-316.

Anderson, R. M., Heesterbeek, H., Klinkenberg, D., \& Hollingsworth, T. D. (2020). How will country-based mitigation measures influence the course of the COVID-19 epidemic? The Lancet, 395(10228), 931-934.

Audretsch, D. B., \& Belitski, M. (2021). Knowledge complexity and firm performance: Evidence from the European SMEs. Journal of Knowledge Management, 25(4), 693-713

Autio, E., George, G., \& Alexy, O. (2011). International entrepreneurship and capability development-Qualitative evidence and future research directions. Entrepreneurship Theory and Practice, 35(1), 11-37.

Ayala, J. C., \& Manzano, G. (2014). The resilience of the entrepreneur. Influence on the success of the business. A longitudinal analysis. Journal of Economic Psychology, 42, 126-135.

Baker, S. R., Bloom, N., Davis, S. J., Kost, K., Sammon, M., \& Viratyosin, T. (2020). The unprecedented stock market reaction to COVID-19. The Review of Asset Pricing Studies, 10(4), 742-758.

Bartik, A. W., Bertrand, M., Cullen, Z. B., Glaeser, E. L., Luca, M., \& Stanton, C. T. (2020). How are small businesses adjusting to COVID-19? Early evidence from a survey (No. w26989). National Bureau of Economic Research, 1-35.

Belitski, M., Guenther, C., Kritikos, A. S., \& Thurik, R. (2021). Economic effects of the COVID-19 pandemic on entrepreneurship and small businesses. Small Business Economics, 1-17.

Bell, E., Bryman, A., \& Harley, B. (2018). Business research methods. Oxford University Press.

Bernard, M. J., \& Barbosa, S. D. (2016). Resilience and entrepreneurship: A dynamic and biographical approach to the entrepreneurial act. M@n@gement, 19(2),89-123.

Bika, Z., \& Kalantaridis, C. (2019). Organizational-social-capital, time and international family SMEs: An empirical study from the east of England. European Management Review, 16(3), 525-541.

Brammer, S., Branicki, L., \& Linnenluecke, M. K. (2020). COVID-19, Societalization, and the Future of Business in Society. Academy of Management Perspectives, 34(4), 493-507.

Branicki, L. J., Sullivan-Taylor, B., \& Livschitz, S. R. (2018). How entrepreneurial resilience generates resilient SMEs. International Journal of Entrepreneurial Behavior \& Research, 24(7), 1244-1263.

Brown, J. S., \& Duguid, P. (1998). Organizing Knowledge. California Management Review, 40(3), 90-111. https:// doi.org/10.2307/41165945.

Bryce, C., Ring, P., Ashby, S., \& Wardman, J. K. (2020). Resilience in the face of uncertainty: Early lessons from the COVID-19 pandemic. Journal of Risk Research, 23(7-8), 880-887.

Bullough, A., \& Renko, M. (2013). Entrepreneurial resilience during challenging times. Business Horizons, 56(3), 343-350.

Bullough, A., Renko, M., \& Myatt, T. (2014). Danger zone entrepreneurs: The importance of resilience and selfefficacy for entrepreneurial intentions. Entrepreneurship Theory and Practice, 38(3), 473-499.

Calabrò, A., Frank, H., Minichilli, A., \& Suess-Reyes, J. (2021). Business families in times of crises: The backbone of family firm resilience and continuity. Journal of Family Business Strategy, https://doi.org/10.1016/j.jfbs. 2021.100442

Carroll, G. R., \& Teo, A. C. (1996). On the social networks of managers. Academy of Management Journal, 39(2), $421-440$.

Chadwick, I. C., \& Raver, J. L. (2020). Psychological resilience and its downstream effects for business survival in nascent entrepreneurship. Entrepreneurship Theory and Practice, 44(2), 233-255.

Chakravarty, A., Grewal, R., \& Sambamurthy, V. (2013). Information Technology Competencies, Organizational Agility, and Firm Performance: Enabling and Facilitating Roles. Information Systems Research, 24(4), 976-997. https://doi.org/10.1287/isre.2013.0500.

Chen, C. C., Ünal, A. F., Leung, K., \& Xin, K. R. (2016). Group harmony in the workplace: Conception, measurement, and validation. Asia Pacific Journal of Management, 33(4), 903-934.

Chrisman, J. J., Chua, J. H., \& Steier, L. P. (2011). Resilience of family firms: An introduction. Entrepreneurship Theory and Practice, 35(6), 1107-1119.

Chrisman, J. J., Chua, J. H., De Massis, A., Minola, T., \& Vismara, S. (2016). Management processes and strategy execution in family firms: From "what" to "how". Small Business Economics, 47(3), 719-734. 
Chrisman, J. J., Memili, E., \& Misra, K. (2014). Nonfamily managers, family firms, and the winner's curse: The influence of noneconomic goals and bounded rationality. Entrepreneurship Theory and Practice, 38(5), 1-25.

Christou, P., Hadjielias, E., \& Farmaki, A. (2019). Reconnaissance of philanthropy. Annals of Tourism Research, 78, 102749.

Chua, J. H., Chrisman, J. J., \& Sharma, P. (1999). Defining the family business by behavior. Entrepreneurship theory and practice, 23(4), 19-39.

Connor, K. M., \& Davidson, J. R. (2003). Development of a new resilience scale: The Connor-Davidson resilience scale (CD-RISC). Depression and Anxiety, 18(2), 76-82.

Conz, E., Lamb, P. W., \& De Massis, A. (2020). Practicing resilience in family firms: An investigation through phenomenography. Journal of Family Business Strategy, 11(2). https://doi.org/10.1016/j.jfbs.2020.100355

Corbin, J., \& Strauss, A. (2014). Basics of qualitative research: Techniques and procedures for developing grounded theory (4th ed.). Sage publications.

Crane, M. F., Kangas, M., Karin, E., Searle, B., \& Chen, D. (2020). Leveraging the experience of stressors: The role of adaptive systematic self-reflection. Anxiety, Stress, \& Coping, 33(3), 231-247.

Dahles, H., \& Susilowati, T. P. (2015). Business resilience in times of growth and crisis. Annals of Tourism Research, $51,34-50$.

Deb, P., \& Wiklund, J. (2017). The Effects of CEO founder status and stock ownership on entrepreneurial orientation in small firms. Journal of Small Business Management, $55(1), 32-55$.

Doern, R. (2021). Knocked down but not out and fighting to go the distance: Small business responses to an unfolding crisis in the initial impact period. Journal of Business Venturing Insights, 15, e00221.

Donthu, N., \& Gustafsson, A. (2020). Effects of COVID-19 on business and research. Journal of Business Research, 117, 284-289.

Dubois, A., \& Gadde, L. E. (2002). Systematic combining: An abductive approach to case research. Journal of business research, 55(7), 553-560.

Etikan, I., Musa, S. A., \& Alkassim, R. S. (2016). Comparison of convenience sampling and purposive sampling. American Journal of Theoretical and Applied Statistics, $5(1), 1-4$.

European Commission (2019). 2019 SBS Fact Sheet: Cyprus. https://ec.europa.eu/docsroom/documents/38662/attac hments/6/translations/en/renditions/native

Fairlie, R., \& Fossen, F. M. (2021). The early impacts of the COVID-19 pandemic on business sales. Small Business Economics, 1-12.

Fandiño, A. M., Formiga, N. S., \& de Menezes, R. M. (2019). Organizational social capital, resilience and innovation validation of a theoretical model for specialized workers. Journal of Strategy and Management., 12(1), 137-152.

Flach, F. F. (1988). Resilience: Discovering a new strength at times of stress. Fawcett Columbine.

Fletcher, D., \& Sarkar, M. (2013). Psychological resilience: A review and critique of definitions, concepts, and theory. European Psychologist, 18(1), 12.
Gabriel, A. S., Diefendorff, J. M., \& Erickson, R. J. (2011). The relations of daily task accomplishment satisfaction with changes in affect: A multilevel study in nurses. Journal of Applied Psychology, 96(5), 1095.

García, M., Castillo, A., \& Durán, V. C. (2012). Online corporate communication: SMEs and differences across sectors. Journal of Organisational Transformation \& Social Change, 9(3), 285-300.

Garmezy, N. (1991). Resiliency and vulnerability to adverse developmental outcomes associated with poverty. American Behavioral Scientist, 34(4), 416-430.

Ghobakhloo, M., \& Tang, S. H. (2013). The role of owner/ manager in adoption of electronic commerce in small businesses: The case of developing countries. Journal of Small Business and Enterprise Development, 20(4), 754-787.

Gibson, B., \& Cassar, G. (2005). Longitudinal analysis of relationships between planning and performance in small firms. Small Business Economics, 25(3), 207-222.

Gioia, D. A., Corley, K. G., \& Hamilton, A. L. (2013). Seeking qualitative rigor in inductive research: Notes on the Gioia methodology. Organizational research methods, 16(1), 15-31.

Gittell, J. H., Cameron, K., Lim, S., \& Rivas, V. (2006). Relationships, layoffs and organizational resilience: Airline responses to crisis of September 11th. Journal of Applied Behavioral Science, 42(3), 300-329.

Gligor, D., Gligor, N., Holcomb, M., \& Bozkurt, S. (2019). Distinguishing between the concepts of supply chain agility and resilience. The International Journal of Logistics Management, 30(2), 467-487.

Glyptis, L., Hadjielias, E., Christofi, M., Kvasova, O., \& Vrontis, D. (2021). Dynamic familiness capabilities and family business growth: A longitudinal perspective framed within management accounting. Journal of Business Research, 127, 346-363.

Goffin, K., \& Koners, U. (2011). Tacit knowledge, lessons learnt, and new product development. Journal of Product Innovation Management, 28(2), 300-318.

Gölgeci, I., \& Kuivalainen, O. (2020). Does social capital matter for supply chain resilience? The role of absorptive capacity and marketing-supply chain management alignment. Industrial Marketing Management, 84, 63-74.

Gray, D. (2017). Developing leadership resilience through a sense of coherence. Contemporary Leadership Challenges, 47.

Grinevich, V., Huber, F., Karataş-Özkan, M., \& Yavuz, Ç. (2019). Green entrepreneurship in the sharing economy: Utilising multiplicity of institutional logics. Small Business Economics, 52(4), 859-876.

Gu, Q., \& Day, C. (2007). Teachers resilience: A necessary condition for effectiveness. Teaching and Teacher education, 23(8), 1302-1316.

Hadjielias, E., Christofi, M., Vrontis, D., \& Khan, H. (2022). Social impact through family firms' interorganizational relationships within a community and a cooperative: An embedded view of stewardship. Journal of Business Research, 139, 584-601.

Hadjielias, E., Christofi, M., \& Tarba, S. (2021). Knowledge hiding and knowledge sharing in small family farms: A 
stewardship view. Journal of Business Research, 137, 279-292.

Hadjimanolis, A. (1999). Barriers to innovation for SMEs in a small less developed country (Cyprus). Technovation, 19(9), 561-570.

Harbi, S. A., Thursfield, D., \& Bright, D. (2017). Culture, Wasta and perceptions of performance appraisal in Saudi Arabia. International Journal of Human Resource Management, 28(19), 2792-2810.

Harries, T., McEwen, L., \& Wragg, A. (2018). Why it takes an 'ontological shock' to prompt increases in small firm resilience: Sensemaking, emotions and flood risk. International Small Business Journal, 36(6), 712-733.

Heck, R. K., \& Trent, E. S. (1999). The prevalence of family business from a household sample. Family Business Review, 12(3), 209-219.

Helfat, C. E., \& Martin, J. A. (2015). Dynamic managerial capabilities: Review and assessment of managerial impact on strategic change. Journal of management, 41(5), 1281-1312.

Herbane, B. (2019). Rethinking organizational resilience and strategic renewal in SMEs. Entrepreneurship \& Regional Development, 31(5-6), 476-495.

Herrero, I., \& Hughes, M. (2019). When family social capital is too much of a good thing. Journal of Family Business Strategy, 10(3), 100271.

Hollensbe, E. C., Khazanchi, S., \& Masterson, S. S. (2008). How do I assess if my supervisor and organization are fair? Identifying the rules underlying entity-based justice perceptions. Academy of Management Journal, 51(6), 1099-1116.

Holton, J. A. (2007). The coding process and its challenges. The Sage handbook of grounded theory, 3, 265-289.

Hutchinson, R. W. (1995). The capital structure and investment decisions of the small owner-managed firm: Some exploratory issues. Small Business Economics, 7(3), 231-239.

Iborra, M., Safón, V., \& Dolz, C. (2019). What explains resilience of SMEs? Ambidexterity capability and strategic consistency. Long Range Planning, 53(6), 101947.

ICAEW (2020). Cyprus' financial response to COVID-19. https://www.icaew.com/insights/features/2020/july-2020/ begin-again-cyprus

Jenkins, A. S., Wiklund, J., \& Brundin, E. (2014). Individual responses to firm failure: Appraisals, grief, and the influence of prior failure experience. Journal of Business Venturing, 29(1), 17-33.

Jiang, Y., Ritchie, B. W., \& Verreynne, M. L. (2019). Building tourism organizational resilience to crises and disasters: A dynamic capabilities view. International Journal of Tourism Research, 21(6), 882-900.

Kalnins, A. (2007). Sample selection and theory development: Implications of firms' varying abilities to appropriately select new ventures. Academy of Management Review, 32(4), 1246-1264.

Kayser, K., Wind, L., \& Shankar, R. A. (2008). Disaster relief within a collectivistic context: Supporting resilience after the tsunami in South India. Journal of Social Service Research, 34(3), 87-98.

Kevill, A., Trehan, K., \& Easterby-Smith, M. (2017). Perceiving 'capability' within dynamic capabilities: The role of owner-manager self-efficacy. International Small Business Journal, 35(8), 883-902.

Khlystova, O., Kalyuzhnova, Y., \& Belitski, M. (2022). The impact of the COVID-19 pandemic on the creative industries: A literature review and future research agenda. Journal of Business Research, 139, 1192-1210.

Kidd, S., \& Shahar, G. (2008). Resilience in homeless youth: The key role of self-esteem. American Journal of Orthopsychiatry, 78(2), 163-172.

Knight, F. H. (1921). Risk, uncertainty and profit (Vol. 31). Houghton Mifflin.

Kollmann, T., Stöckmann, C., Meves, Y., \& Kensbock, J. M. (2017). When members of entrepreneurial teams differ: linking diversity in individual-level entrepreneurial orientation to team performance. Small Business Economics, 48(4), 843-859.

Kong, F., Wang, X., Hu, S., \& Liu, J. (2015). Neural correlates of psychological resilience and their relation to life satisfaction in a sample of healthy young adults. Neuroimage, 123, 165-172.

Korber, S., \& McNaughton, R. B. (2018). Resilience and entrepreneurship: A systematic literature review. International Journal of Entrepreneurial Behavior \& Research, 24(7), 1129-1154.

Lai, Y., Saridakis, G., Blackburn, R., \& Johnstone, S. (2016). Are the HR responses of small firms different from large firms in times of recession? Journal of Business Venturing, 31(1), 113-131.

Langowitz, N. S., \& Allen, I. E. (2010). Small business leadership: Does being the founder matter? Journal of Small Business \& Entrepreneurship, 23(1), 53-63.

Lee, J. E., Sudom, K. A., \& Zamorski, M. A. (2013). Longitudinal analysis of psychological resilience and mental health in Canadian military personnel returning from overseas deployment. Journal of Occupational Health Psychology, 18(3), 327-337.

Leonidou, L. C., Christodoulides, P., \& Thwaites, D. (2016a). External determinants and financial outcomes of an eco-friendly orientation in smaller manufacturing firms. Journal of Small Business Management, 54(1), 5-25.

Leonidou, L. C., Christodoulides, P., \& Thwaites, D. (2016b). External determinants and financial outcomes of an eco-friendly orientation in smaller manufacturing firms. Journal of Small Business Management, 54(1), 5-25.

Lichtenstein, B. M. B., \& Brush, C. G. (2001). How do "resource bundles" develop and change in new ventures? A dynamic model and longitudinal exploration. Entrepreneurship Theory and Practice, 25(3), 37-58.

Liu, S., Wang, M., Bamberger, P., Shi, J., \& Bacharach, S. B. (2015). The dark side of socialization: A longitudinal investigation of newcomer alcohol use. Academy of Management Journal, 58(2), 334-355.

Lozano, M. B., Martínez, B., \& Pindado, J. (2016). Corporate governance, ownership and firm value: Drivers of ownership as a good corporate governance mechanism. International Business Review, 25(6), 1333-1343.

Mandl, I. (2008). Overview of family business relevant issues. Contract, (30-CE), 0164021.

Mc Cartan-Quinn, D., \& Carson, D. (2003). Issues which impact upon marketing in the small firm. Small business economics, 21(2), 201-213. 
McAdam, M., Harrison, R. T., \& Leitch, C. M. (2019). Stories from the field: Women's networking as gender capital in entrepreneurial ecosystems. Small Business Economics, 53(2), 459-474.

McKibbin, W., \& Fernando, R. (2020). The economic impact of COVID-19. Economics in the Time of, COVID-19, 45-51.

McKinsey \& Company (2020). COVID-19 in the United Kingdom: Assessing jobs at risk and the impact on people and places. https://www.mckinsey. $\mathrm{com} / \mathrm{indus}$ tries/public-and-social-sector/ourinsights/covid-19-in-the-united-kingdom-asses sing-jobs-at-risk-and-the-impact-on-people-and-places

Miller, D., \& Le Breton-Miller, I. (2006). Family governance and firm performance: Agency, stewardship, and capabilities. Family business review, 19(1), 73-87.

Moenkemeyer, G., Hoegl, M., \& Weiss, M. (2012). Innovator resilience potential: A process perspective of individual resilience as influenced by innovation project termination. Human Relations, 65(5), 627-655.

Mosey, S., \& Wright, M. (2007). From human capital to social capital: A longitudinal study of technology-based academic entrepreneurs. Entrepreneurship Theory and Practice, 31(6), 909-935.

Nepal, S. K. (2020). Travel and tourism after COVID-19-business as usual or opportunity to reset? Tourism Geographies, 22(3), 646-650.

Ortiz-de-Mandojana, N., \& Bansal, P. (2016). The long-term benefits of organizational resilience through sustainable business practices. Strategic Management Journal, 37(8), 1615-1631.

Owen, R., Deakins, D., \& Savic, M. (2019). Finance pathways for young innovative small-and medium-size enterprises: A demand-side examination of finance gaps and policy implications for the post-global financial crisis finance escalator. Strategic Change, 28(1), 19-36.

Pal, R., Torstensson, H., \& Mattila, H. (2014). Antecedents of organizational resilience in economic crises-An empirical study of Swedish textile and clothing SMEs. International Journal of Production Economics, 147, 410-428.

Pan, B., MacLaurin, T., \& Crotts, J. C. (2007). Travel blogs and the implications for destination marketing. Journal of travel research, 46(1), 35-45.

Pantano, E., Pizzi, G., Scarpi, D., \& Dennis, C. (2020). Competing during a pandemic? Retailers' ups and downs during the COVID-19 outbreak. Journal of Business Research, 116, 209-213.

Petrou, A. P., Hadjielias, E., Thanos, I. C., \& Dimitratos, P. (2020). Strategic decision-making processes, international environmental munificence and the accelerated internationalization of SMEs. International Business Review, 29(5), 101735

Pratt, M. G. (2009). From the editors: For the lack of a boilerplate: Tips on writing up (and reviewing) qualitative research. Academy of Management Journal, 52(5), 856-862.

PWC (May 2020). COVID-19 - Impact of the pandemic on the Cyprus economy. https://www.pwc.com.cy/en/publi cations/assets/pwc-covid-19-impact-on-cyprus-economymay-2020.pdf
Ramezani, J., \& Camarinha-Matos, L. M. (2020). Approaches for resilience and antifragility in collaborative business ecosystems. Technological Forecasting and Social Change, 151, 119846.

Ratten, V. (2020). Coronavirus disease (COVID-19) and sport entrepreneurship. International Journal of Entrepreneurial Behavior \& Research, 26(6), 1379-1388.

Renko, M., Bullough, A., \& Saeed, S. (2021). How do resilience and self-efficacy relate to entrepreneurial intentions in countries with varying degrees of fragility? A six-country study. International Small Business Journal, $39(2), 130-156$.

Reuters (2021). Cyprus to ease lockdown measures gradually after fall in COVID cases. https://www.reuters.com/artic le/us-health-coronavirus-cyprus-idUSKBN29W1ET

Roggeveen, A. L., \& Sethuraman, R. (2020). How the COVID19 pandemic may change the world of retailing. Journal of Retailing, 96(2), 169.

Rousseau, M. B., Kellermanns, F., Zellweger, T., \& Beck, T. E. (2018). Relationship conflict, family name congruence, and socioemotional wealth in family firms. Family Business Review, 31(4), 397-416.

Salvato, C., \& Melin, L. (2008). Creating value across generations in family-controlled businesses: The role of family social capital. Family Business Review, 21(3), 259-276.

Salvato, C., Sargiacomo, M., Amore, M. D., \& Minichilli, A. (2020). Natural disasters as a source of entrepreneurial opportunity: Family business resilience after an earthquake. Strategic Entrepreneurship Journal, 14(4), 594-615.

Santoro, G., Bertoldi, B., Giachino, C., \& Candelo, E. (2018). Exploring the relationship between entrepreneurial resilience and success: The moderating role of stakeholders' engagement. Journal of Business Research, 119, $142-150$.

Santoro, G., Messeni-Petruzzelli, A., \& Del Giudice, M. (2021). Searching for resilience: The impact of employee-level and entrepreneur-level resilience on firm performance in small family firms. Small Business Economics, 57(1), 455-471.

Schonfeld, I. S., \& Mazzola, J. J. (2015). A qualitative study of stress in individuals self-employed in solo businesses. Journal of Occupational Health Psychology, 20(4), 501-513.

Seetharaman, P. (2020). Business models shifts: Impact of COVID-19. International Journal of Information Management, 54, 102173.

Shailer, G. (1994). Capitalists and entrepreneurs in owner-managed firms. International Small Business Journal, 12(3), 33-41.

Shams, R., Vrontis, D., Belyaeva, Z., Ferraris, A., \& Czinkota, M. R. (2021). Strategic agility in international business: A conceptual framework for "agile" multinationals. Journal of International Management, 27(1), 100737. https:// doi.org/10.1016/j.intman.2020.100737.

Sharma, P., Leung, T. Y., Kingshott, R. P., Davcik, N. S., \& Cardinali, S. (2020). Managing uncertainty during a global pandemic: An international business perspective. Journal of business research, 116, 188-192.

Shepherd, D. A., Saade, F. P., \& Wincent, J. (2020). How to circumvent adversity? Refugee-entrepreneurs' resilience 
in the face of substantial and persistent adversity. Journal of Business Venturing, 35(4). https://doi.org/10.1016/j. jbusvent.2019.06.001

Shin, J., Taylor, M. S., \& Seo, M. G. (2012). Resources for change: The relationships of organizational inducements and psychological resilience to employees' attitudes and behaviors toward organizational change. Academy of Management journal, 55(3), 727-748.

Sillince, J., Jarzabkowski, P., \& Shaw, D. (2012). Shaping strategic action through the rhetorical construction and exploitation of ambiguity. Organization Science, 23(3), 630-650.

Smith, C. L. (2015). How coaching helps leadership resilience: The leadership perspective. International Coaching Psychology Review, 10(1), 6-19.

Stein, M. (2015). Double trouble: Sibling rivalry and twin organizations in the 2008 credit crisis. British Journal of Management, 26(2), 182-196.

Teece, D. J., Pisano, G., \& Shuen, A. (1997). Dynamic capabilities and strategic management. Strategic management journal, 18(7), 509-533.

Teece, D., Peteraf, M., \& Leih, S. (2016). Dynamic capabilities and organizational agility: Risk, uncertainty, and strategy in the innovation economy. California management review, 58(4), 13-35.

The European Investment Bank (2021). European Investment Bank survey suggests $51 \%$ Cypriot firms have cut investment during COVID-19 pandemic. https://www.eib.org/ en/press/all/2021-080-eib-survey-suggests-51-cypriotfirms-have-cut-investment-during-covid-19-pandemic

Theodoraki, C., Messeghem, K., \& Rice, M. P. (2018). A social capital approach to the development of sustainable entrepreneurial ecosystems: An explorative study. Small Business Economics, 51(1), 153-170.

Timmermans, S., \& Tavory, I. (2012). Theory construction in qualitative research: From grounded theory to abductive analysis. Sociological Theory, 30(3), 167-186.

Torrès, O., Benzari, A., Fisch, C., Mukerjee, J., Swalhi, A., \& Thurik, R. (2021). Risk of burnout in French entrepreneurs during the COVID-19 crisis. Small Business Economics, 1-23.
Torres, A. P., Marshall, M. I., \& Sydnor, S. (2019). Does social capital pay off? The case of small business resilience after Hurricane Katrina. Journal of Contingencies and Crisis Management, 27(2), 168-181.

Tsang, E. W. (2013). Case study methodology: Causal explanation, contextualization, and theorizing. Journal of International Management, 19(2), 195-202.

Tseng, Y. H., \& Lin, C. T. (2011). Enhancing enterprise agility by deploying agile drivers, capabilities and providers. Information Sciences, 181(17), 3693-3708.

Tugade, M. M., \& Fredrickson, B. L. (2004). Resilient individuals use positive emotions to bounce back from negative emotional experiences. Journal of Personality and Social Psychology, 86(2), 320.

Vyakarnam, S., \& Handelberg, J. (2005). Four themes of the impact of management teams on organizational performance: Implications for future research of entrepreneurial teams. International Small Business Journal, 23(3), 236-256.

Weber, Y., \& Tarba, S. Y. (2014). Strategic agility: A state of the art introduction to the special section on strategic agility. California Management Review, 56(3), 5-12.

Werner, A., Schröder, C., \& Chlosta, S. (2018). Driving factors of innovation in family and non-family SMEs. Small Business Economics, 50(1), 201-218.

Williams, T. A., \& Shepherd, D. A. (2016). Building resilience or providing sustenance: Different paths of emergent ventures in the aftermath of the Haiti earthquake. Academy of Management Journal, 59(6), 2069-2102.

Yin, R. K. (2018). Case study research and applications: design and methods (6th ed.). Sage publications.

Zahra, S. A., Wright, M., \& Abdelgawad, S. G. (2014). Contextualization and the advancement of entrepreneurship research. International Small Business Journal, 32(5), 479-500.

Publisher's note Springer Nature remains neutral with regard to jurisdictional claims in published maps and institutional affiliations. 